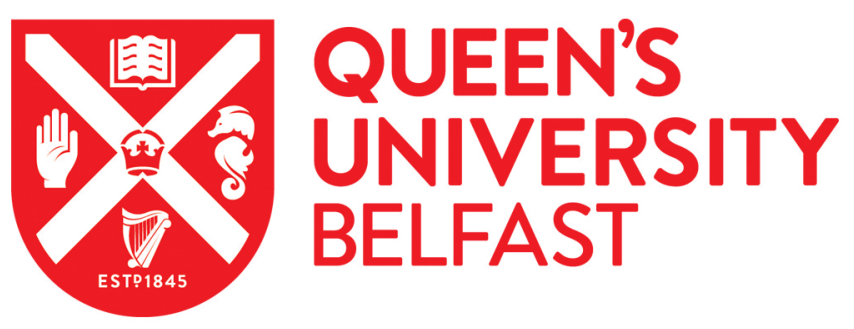

\title{
The NORM4Building database, a tool for radiological assessment when using by-products in building materials
}

Schroeyers, W., Sas, Z., Bator, G., Trevisi, R., Nuccetelli, C., Leonardi, F., Schreurs, S., \& Kovacs, T. (2018). The NORM4Building database, a tool for radiological assessment when using by-products in building materials. Construction and Building Materials, 159, 755-767. https://doi.org/10.1016/j.conbuildmat.2017.11.037

Published in:

Construction and Building Materials

Document Version:

Peer reviewed version

Queen's University Belfast - Research Portal:

Link to publication record in Queen's University Belfast Research Portal

Publisher rights

(c) 2017 Elsevier Ltd. All rights reserved.

This manuscript version is made available under the CC-BY-NC-ND 4.0 license http://creativecommons.org/licenses/by-nc-nd/4.0/,which permits distribution and reproduction for noncommercial purposes, provided the author and source are cited.

\section{General rights}

Copyright for the publications made accessible via the Queen's University Belfast Research Portal is retained by the author(s) and / or other copyright owners and it is a condition of accessing these publications that users recognise and abide by the legal requirements associated with these rights.

Take down policy

The Research Portal is Queen's institutional repository that provides access to Queen's research output. Every effort has been made to ensure that content in the Research Portal does not infringe any person's rights, or applicable UK laws. If you discover content in the Research Portal that you believe breaches copyright or violates any law, please contact openaccess@qub.ac.uk. 
THE NORM4BUILDING DATABASE, A TOOL FOR RADIOLOGICAL

ASSESSMENT WHEN USING BY-PRODUCTS IN BUILDING MATERIALS

Wouter Schroeyers ${ }^{1 *}$,Zoltan Sas ${ }^{1,2}{\text { Gergo } \text { Bator }^{3} \text {, Rosabianca Trevisi }}^{4}$, Cristina Nuccetelli ${ }^{5}$, Federica Leonardi ${ }^{4}$, Sonja Schreurs ${ }^{1}$, Tibor Kovacs ${ }^{3}$

${ }^{1}$ Hasselt University, CMK, NuTeC, Nuclear Technology - Faculty of Engineering Technology, Agoralaan building H, B-3590 Diepenbeek, Belgium

${ }^{2}$ School of Natural and Built Environment, Queen's University Belfast, David Keir Bldg., 39-123 Stranmillis Rd, Belfast BT9 5AG, United Kingdom

${ }^{3}$ University of Pannonia, Institute of Radiochemistry and Radioecology, H-8200, Egyetem St. 10., d Veszprém, Hungary

4 INAIL (National Institute for Insurance against Accidents at Work)- Research Sector, DiMEILA, Via di Fontana Candida 100078 Monteporzio Catone (Rome), Italy

5ISS (National Institute of Health), Technology and Health Department, Viale Regina Elena, 299, Rome, Italy

\title{
Highlights
}

*Wouter.schroeyers@uhasselt.be

- Datamining was used for the construction of the NORM4Building database

- Systematic radiological evaluation of by-products for use in concrete

- Radiological evaluation of cement, concrete, ceramics and (phospo)gypsum

- The datamining approach enables the construction of an updated detailed database

\begin{abstract}
Scientific data on natural occurring radioactive materials (NORMs) is available in unknown quantities and the data is fragmented over several different sources. The new EU-BSS is regulating the use of NORM in building materials, however a large scale database with country specific information that can support legislators and industry in the assessment of the radiological impact of the use of by-products in construction is missing. Currently the COST Action 'NORM4BUILDING' (2014-2017) is creating such a database using a semi-automated datamining approach. In this paper radiological aspects on by-products that can find application in concrete are discussed based on the database.
\end{abstract}

\section{Key-words}

Natural occurring radioactive materials, building materials, database, concrete, by-products, Euratom Basic Safety Standards 


\section{Introduction}

Europe is evolving to a more resource controlled continent. This transition is driven by the EU action plan on developing a circular economy [1] and supported by the waste framework directive [2]. The constituents of more and more construction materials, and in particular building materials, are being replaced with by-products from several industrial sectors. Upon replacing raw materials by by-products that contain increased concentrations of naturally occurring radionuclides care needs to be taken to ensure that the newly produced construction materials meet the radiological protection standards of the EU and its Member States. The new Euratom Basic Safety Standards (EU-BSS) [3] were published in 2014 and contain requirements for industrial sectors involving Naturally Occurring Radioactive Materials (NORMs) and the use of specific residues from the considered industrials sectors in building materials. The EU-BSS is expected to be transposed in national and regional legislations by February 6, 2018 for all the member states of the EU. Worldwide the safe use of NORM is also becoming increasingly important. The new IAEA-BSS (Radiation protection and safety of radiation sources: international basis safety standards) [4] was also published in 2014. Both the EU-BSS and the IAEA-BSS are based on ICRP recommendation 103 [5]. Simulated and experimental data originating from scientific papers dealing with NORMs are gathered in UNSCEAR reports [6] and these form the basis of the ICRP recommendations.

A major challenge regarding the collection of data on NORM and NORM-containing construction materials is that literature data is fragmented over a lot of different sources. It is even unclear to which extend country-specific literature data is available. Only a limited number of data sets, all of them manually collected, are available. Trevisi et al. [7] collected a lot of data on activity concentration measurements of natural radionuclides $\left({ }^{226} \mathrm{Ra},{ }^{232} \mathrm{Th}\right.$ and $\left.{ }^{40} \mathrm{~K}\right)$ in building materials used in 26 of 27 EU Member States. Sas et al. [8] constructed a database ('By-BM database') by collecting data on raw materials, by-products and construction materials from 48 countries. Next to this database the NORM database of NIRS (National Institute of Radiological Sciences, Japan) [9] is available but it lacks data on European NORM or construction materials.

Currently the COST Action Tu1301 'NORM4BUILDING' (2014-2017) is creating an extensive database gathering radiological data on NORMs and construction materials in which NORM containing by-products are implemented. The COST Action closely collaborates with the "MetroNORM" project (MetroNORM - Metrology for processing materials with high natural radioactivity) [10], involving several European NMIs (National Metrological Institutes), to develop standardized measurement protocols for NORM and NORM-containing 
construction materials. In the current paper, the contents of the NORM4BUILDING database is presented and discussed.

For the collection of large amounts of data, there is a need for a systematic, as much as possible automatized, approach to data mining to investigate the different fragmented sources of data. Upon using an automatized approach of gathering scientific data, a crucial scientific challenge is the validation and selection of data for incorporation in the database, an aspect which is especially complicated when dealing with NORM. For the characterization of NORM ISO standards and standardized measurement and sampling procedures are still under development. The analytical determination of the activity concentrations of natural radionuclides in NORM samples requires specialized knowledge. Not all papers deal appropriately with the absence of secular equilibrium which in general is the rule for many industrial by-products and construction materials that are based on these by-products. The current paper describes in more detail the methodology used for the semi-automatized data mining approach that was developed to build the NORM4Building database.

Based on the information collected in the NORM4Building database, this study aims to give a realistic evaluation of the radiological properties of construction materials based on NORM byproducts using the criteria set by the EU-BSS. 


\section{Materials \& methods}

\subsection{Data mining for data collection}

A data mining approach was used as an analytical method to extract information regarding NORM, i.e. raw materials (ores), by-products, and NORM-containing construction materials from published papers. The text mining method [11], a process of analysing collections of textual materials to capture key concepts, basic parameters, keywords and to uncover hidden relationships and trends, was applied.

The main milestones of the data mining process are the following and show the Figure 1:

1. Automatic keyword driven selection of papers,

2. Building and applying filters based on selected keywords,

3. Handling different types of publications into the IBM SPSS Modeler ${ }^{\mathrm{TM}}$ software to extract information using natural language processing (NLP),

4. Extracting complete measurement results and origin (Country) from relevant publications available in different formats such as: Microsoft Word ${ }^{\mathrm{TM}}$, Microsoft Excel $^{\mathrm{TM}}$, and Microsoft PowerPoint ${ }^{\mathrm{TM}}$, as well as Adobe PDFTM ${ }^{\mathrm{T}}$ XL, HTML,

5. Applying Text Link Analysis (TLA) to define pattern rules and to compare these to relationships found in the text,

6. Structuring the collected data.

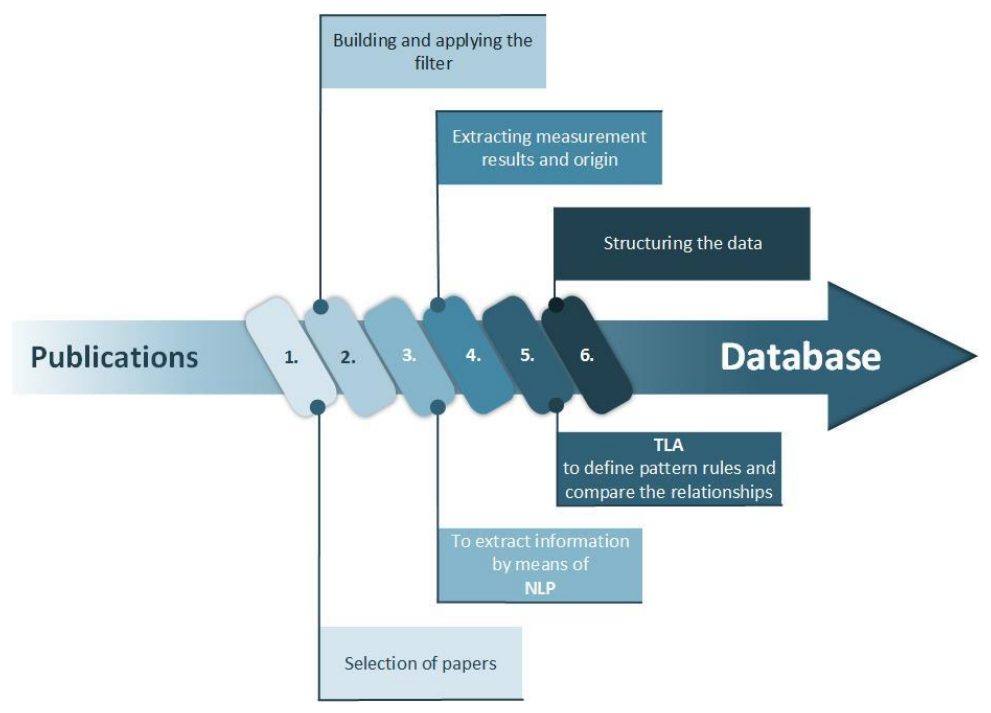

Figure 1 The main milestones of data mining process,

Publications from different electronic sources, such as Science Direct, Web of Science and others (IAEA and ICRP documents, National Surveys, etc.) have been processed. After applying the filter, relevant publications, which contain measurement results for activity, activity concentration, or exhalation rate were extracted. The next step was to identify the specific keywords related to these results. At the beginning of the COST project, a trial database, was built manually including 16 types of materials extracted from approximately 100 publications. To expand the list of keywords beyond these material types text link analysis (TLA) was used. TLA is a pattern-matching technology that enables to define pattern rules and 
compare the pattern rules to the concepts present in text of the extracted documents. Applying TLA resulted of in a lot of false-positive matches, where the concept found is not a material of interest and is not relevant for data collection. By browsing the list and selecting relevant concepts the materials list (the list of keywords) was expanded from 16 to 59 types of materials excluding general expressions. In the publications, two types of measurement information were identified: tables listing the results and grammatically complete results definitions. Both types of information require different ways of extraction because the date is structurally organized differently. Both strategies for data collection have in common that they involve library building, so the information is imported into a library. A disadvantage is that in its current version the automatic data collection approach cannot handle figures.

The geological origin of the studied materials is very relevant for the radiological properties of the studied materials. In addition, country specific circumstances (legislation, dominant industrial sectors, accessible resources, etc.) determine the properties and use of investigated materials and therefore the database aims at providing country specific information.

\subsection{Validation of entries}

Upon selecting the data for inclusion in a database, important aspects need to be controlled: (1) The reliability of the data used needs to be verified. (2) Another problem in data selection is that measurement results are sometimes repeated in several publications: new papers can be based on previous results and in a way measurement results can then be reported in double or even in multiple times in different sources. In this way, the data can be overrated in data analysis. (3) In numerous papers, the number of samples measured is not clearly reported.

The method used to solve these problems and validate the database data, identifying correct and useful data, was a careful reading after the final collection step. Additional analysis of the text allowed to individuate, in many cases, the number of samples. When this procedure did not succeed, the number of samples was considered as 1 ; that is why the total number of data in the database is certainly an underestimation. As regards to the problem of same data from different papers, a careful reading of text and references was necessary to verify if data was new or already considered from other included papers.

\subsection{Database content $\&$ structure}

The total number of entries in the database is 1422 and the total number of samples is 12365 (date: 01/07/2017). The database contains data on 26 (No data was found for Latvia and Malta) of the 28 Member States of the European Union and all together for 74 countries worldwide. An initial report on the start-up version of the NORM4Building database was given in [12]. 
Table 1 References investigated for a given material from a specific country

\begin{tabular}{|c|c|c|c|c|c|c|c|}
\hline \multicolumn{2}{|c|}{ Blast furnace slag } & Malaysia & {$[13][14][15]$} & \multicolumn{2}{|c|}{ Copper slag } & Germany & [7] \\
\hline Croatia & $=[16][17]$ & Norway & [13] & Germany & [18] & Greece & {$[7][19][20]$} \\
\hline Egypt & {$[21]$} & Pakistan & $\begin{array}{l}{[13][22][23]} \\
{[24]}\end{array}$ & Poland & [25] & India & {$[26]$} \\
\hline Germany & {$[18]$} & Poland & [27] & \multicolumn{2}{|c|}{ Fly ash } & Iran & {$[28]$} \\
\hline Spain & [29] & \begin{tabular}{|l|} 
Portugal \\
\end{tabular} & [27] & Australia & {$[30]$} & Israel & [19] \\
\hline Turkey & {$[31][32]$} & Qatar & {$[33]$} & Canada & [34] & Jordan & {$[35]$} \\
\hline \multicolumn{2}{|c|}{ Bottom ash } & \begin{tabular}{|l|} 
Romania \\
\end{tabular} & {$[27][36][37]$} & China & [38][39] & Korea & [19] \\
\hline Australia & {$[40]$} & Slovakia & {$[27][41]$} & Greece & $\begin{array}{l}{[42][43][44]} \\
{[45][46]}\end{array}$ & Morocco & [47] \\
\hline Canada & {$[34]$} & Spain & [27][29] & India & $\begin{array}{l}{[48][49][50]} \\
{[51]}\end{array}$ & Nigeria & {$[52]$} \\
\hline China & {$[38][39]$} & Sweden & {$[27]$} & Ireland & [53] & Poland & {$[7][54]$} \\
\hline Greece & {$[46][45][55]$} & $\begin{array}{l}\text { The } \\
\text { Netherlands }\end{array}$ & {$[13][27][56]$} & Italy & [55] & Romania & [7][57] \\
\hline Ireland & [53] & Turkey & $\begin{array}{l}{[13][58][59]} \\
{[60]}\end{array}$ & Kosovo & [55] & Serbia & [61] \\
\hline Italy & [55] & $\begin{array}{l}\text { United } \\
\text { Kingdom }\end{array}$ & [27] & Philippines & [62] & Slovenia & [7] \\
\hline Kosovo & [55] & Zambia & {$[63]$} & \multirow[t]{2}{*}{ Poland } & \multirow[t]{2}{*}{ [54] } & Spain & {$[19][64][65]$} \\
\hline Philippines & {$[62]$} & \multicolumn{2}{|c|}{ Ceramics } & & & Syria & {$[66]$} \\
\hline Serbia & [55] & China & [67] & Serbia & {$[68]$} & Tanzania & [69] \\
\hline Spain & {$[70]$} & Egypt & [71] & Slovakia & [41] & $\begin{array}{l}\text { The } \\
\text { Netherlands }\end{array}$ & [7] \\
\hline \multirow[t]{2}{*}{ Syria } & \multirow[t]{2}{*}{ [72] } & Italy & [67] & Spain & {$[29][70]$} & Turkey & $\begin{array}{l}19][32][73] \\
\end{array}$ \\
\hline & & Spain & [67] & Syria & {$[72]$} & $\begin{array}{l}\text { United } \\
\text { Kingdom }\end{array}$ & {$[7]$} \\
\hline Turkey & {$[55][74]$} & \multicolumn{2}{|c|}{ Concrete } & Turkey & $\begin{array}{l}{[32][55][58]} \\
{[74][75]}\end{array}$ & United States & [76] \\
\hline \multicolumn{2}{|c|}{ Cement } & Austria & [7] & United States & [77] & \multicolumn{2}{|c|}{ Red mud } \\
\hline Australia & 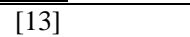 & \begin{tabular}{|l|} 
Belgium \\
\end{tabular} & [7] & \multicolumn{2}{|c|}{ Gypsum } & Australia & $=[27][78]$ \\
\hline Austria & [27] & Bulgaria & [7] & Bulgaria & [79] & Brazil & [27] \\
\hline Bangladesh & [13] & China & [80] & Egypt & [71] & China & [27] \\
\hline Belgium & [27] & $\begin{array}{l}\text { Czech } \\
\text { Republic } \\
\end{array}$ & [7] & Estonia & [81] & Germany & {$[27][47]$} \\
\hline Brazil & {$[13][79]$} & Denmark & [7] & Iran & [79] & Greece & [27] \\
\hline Bulgaria & {$[27]$} & Estonia & [81] & Italy & [82] & Hungary & [27][83] \\
\hline Cameroon & [73] & Finland & [7] & Lebanon & [84] & Italy & {$[27]$} \\
\hline China & $\begin{array}{l}{[80][85][86]} \\
{[87]}\end{array}$ & France & [7] & Pakistan & [79] & Jamaica & [27] \\
\hline Cyprus & [67] & Germany & [7] & Syria & [79] & Romania & {$[88]$} \\
\hline $\begin{array}{l}\text { Czech } \\
\text { Republic }\end{array}$ & [27] & Greece & [7] & Turkey & {$[32][79][89]$} & Turkey & [27] \\
\hline Denmark & [27] & Hungary & [90] & \multicolumn{2}{|c|}{ Lead slag } & \multicolumn{2}{|c|}{ Steel slag } \\
\hline Egypt & $\begin{array}{l}{[71][91][92]} \\
{[93]}\end{array}$ & Ireland & [7] & Germany & {$[18]$} & China & [94] \\
\hline Estonia & [81] & Italy & [7] & \multicolumn{2}{|c|}{ Nickel slag } & Croatia & {$[17][95]$} \\
\hline Finland & {$[27]$} & Lithuania & [7] & Germany & {$[18]$} & Germany & {$[18]$} \\
\hline France & {$[27]$} & Luxembourg & [7] & Poland & [25] & Greece & [96] \\
\hline Germany & {$[27]$} & \begin{tabular}{|l|} 
Poland \\
\end{tabular} & [97] & \multicolumn{2}{|c|}{ Phosphogypsum } & Romania & [98][99] \\
\hline Greece & {$[27][100][101]$} & Portugal & [7] & Australia & {$[30]$} & $\begin{array}{l}\text { The } \\
\text { Netherlands }\end{array}$ & {$[102]$} \\
\hline Hungary & [27] & Romania & [7] & Bangladesh & [19] & $\begin{array}{l}\text { United } \\
\text { Kingdom }\end{array}$ & {$[103]$} \\
\hline India & {$[79][104][105]$} & Slovakia & [41] & Belgium & [7] & \multicolumn{2}{|c|}{ Tin slag } \\
\hline Iran & [79] & Slovenia & {$[7]$} & Brazil & $\begin{array}{l}{[106][107]} \\
{[108][109]} \\
{[110][111]}\end{array}$ & Germany & {$[18]$} \\
\hline Ireland & {$[27][112]$} & Spain & [29] & Bulgaria & [7] & Malaysia & {$[113][114]$} \\
\hline Italy & {$[13][27][115]$} & Syria & [116] & $\begin{array}{l}\text { Czech } \\
\text { Republic }\end{array}$ & [7] & $\begin{array}{l}\text { United } \\
\text { Kingdom }\end{array}$ & {$[117]$} \\
\hline Japan & [13] & $\begin{array}{l}\text { The } \\
\text { Netherlands }\end{array}$ & [7] & Egypt & $\begin{array}{l}{[19][47][71]} \\
{[91][118]}\end{array}$ & & \\
\hline Lebanon & {$[84]$} & $\begin{array}{l}\text { United } \\
\text { Kingdom }\end{array}$ & [7] & Finland & [7] & & \\
\hline
\end{tabular}

The data are classified into 3 main categories:

- Primary raw materials - coal (coal, lignite, peat, bituminous coal), phosphate ores, ferrous ores (iron ores such as hematite, limonite, magnetite), non-ferrous ores and minerals (aluminium ore (bauxite), gold ore, manganese ore, molybdenum ore, 
monazite, nickelic ore, titanium ore, uranium rocks, zirconium ore, ilmenite, rutile, baddeleyite) and other natural rocks or sands (basalt, black sand, chalk, chert, clay (or clay minerals such as kaolinite), diabase rock, dolomite, gabbro, granite, gravel, marble (composed out of calcite or dolomite), marl (or marlstone), pumice, quartzite, sand, sandstone, schist, serpentinite, soil, stone, trass, tuff),

- (By)-products - red mud, fly ash, bottom ash, different types of slags (iron slag, steel slag, coal slag, copper slag, blast furnace slag...), and other materials (calcium carbonate, cerium oxide, copper, corundum, fertilizer material, iron oxide, mud, sludge, titanium dioxide, dross, tailing, scale...),

- Construction materials - cement, ceramics, concrete, phosphogypsum, gypsum and other materials (bricks, clinker, gas silicate blocks, plaster, adobe, mortar...).

The current paper limits itself to specific by-products, considered by the EU-BSS, that are likely to be used as a building material and on building materials such as concrete, ceramics and (phospo)gypsum. In total the current paper considers a selection of 460 entries (7705 samples) from the database. The references from which the extracted data (for a given country) originates are given in Table 1. From one reference several different entries linked to different types of samples can be extracted for a given country or from different countries. For most countries, the results are not statistically representative at the national level due to the low number of data available in the literature.

\subsection{Scenarios for incorporation of by-products}

The concrete compositions listed in Table 2 were used to model the use of by-products in concrete and to calculate the activity concentration index (I-index) for concrete including a given type of by-product using the activity concentration index defined in [119] and given in equation 1:

$I-$ index $=\frac{A c_{226 R a}}{300 B q / k g}+\frac{A c_{232 T h}}{200 B q / k g}+\frac{A c_{40 K}}{3000 B q / k g}$

With Ac as activity concentration of the mentioned radionuclide expressed in $\mathrm{Bq} / \mathrm{kg}$. 


\begin{tabular}{|c|c|c|c|c|c|}
\hline \multirow{2}{*}{$\begin{array}{l}\text { Scenario } \\
\text { ID }\end{array}$} & \multirow[t]{2}{*}{ Construction Material } & \multicolumn{4}{|c|}{ Composition $\left(\mathrm{kg} / \mathrm{m}^{3}\right)$} \\
\hline & & Cement & $\begin{array}{c}\text { By- } \\
\text { product }\end{array}$ & Aggregates & Water \\
\hline 1 & Reference concrete & 400 & & 1850 & 150 \\
\hline 2 & $\begin{array}{l}\text { High volume fly ash (HVFA) } \\
\text { concrete }\end{array}$ & 160 & $\begin{array}{l}220 \text { (fly ash } \\
\quad(\text { FA) })\end{array}$ & 1700 & 140 \\
\hline 3 & $\begin{array}{l}\text { Concrete with FA as partial } \\
\text { replacement of cement and sand' }\end{array}$ & 320 & $130(\mathrm{FA})$ & 1750 & 150 \\
\hline 4 & $\begin{array}{l}\text { Concrete with FA as partial } \\
\text { replacement of sand }\end{array}$ & 360 & $90(\mathrm{FA})$ & 1800 & 150 \\
\hline 5 & $\begin{array}{l}\text { Concrete with slag as partial } \\
\text { replacement of cement and } \\
\text { aggregates' }\end{array}$ & 80 & 720 (slag) & 1850 & 150 \\
\hline 6 & $\begin{array}{l}\text { Concrete with slag as partial } \\
\text { replacement of cement }\end{array}$ & 80 & 320 (slag) & 1850 & 150 \\
\hline 7 & $\begin{array}{l}\text { Concrete with slag as partial } \\
\text { replacement of aggregates' }\end{array}$ & 400 & 400 (slag) & 1450 & 150 \\
\hline 8 & $\begin{array}{l}\text { Alkali activated concrete containing } \\
\text { red mud as partial replacement of } \\
\text { cement and aggregates }\end{array}$ & & $\begin{array}{l}1800 \text { (red } \\
\text { mud) }\end{array}$ & 450 & 150 \\
\hline
\end{tabular}

In the calculation of the I-index, for a specific type of concrete, the considered percentages of by-product incorporation correspond to a specific scenario from Table 2. As I-indexes for respectively cement and soil/aggregates the average values of 0.38 and 0.45 were used in the calculations [7].

\section{Results}

The EU-BSS [3] introduces a two steps pathway to control the gamma dose from both natural building materials and building materials incorporating by-products: (1) the EU-BSS uses the activity concentration index (I-index) as a conservative tool for the initial screening of building materials. (2) In case of an I-index exceeding the value of 1, the external gamma dose has to be accurately assessed accounting for the reference level of $1 \mathrm{mSv} / \mathrm{y}$ for exposure of gamma. A more accurate evaluation of the effective dose can take into account density and thickness of the final material and partition factor of its constituents if the constituents are produced by industrial sectors involving NORM. 
In the evaluation below, the criteria set by the EU-BSS are used for the evaluation of the selected entries from the NORM4Building database. In this way, literature results on byproducts that are considered for use in building materials and studies that exist on the building materials themselves will be evaluated.

\subsection{Combustion products from coal, peat and heavy oil fired power plants}

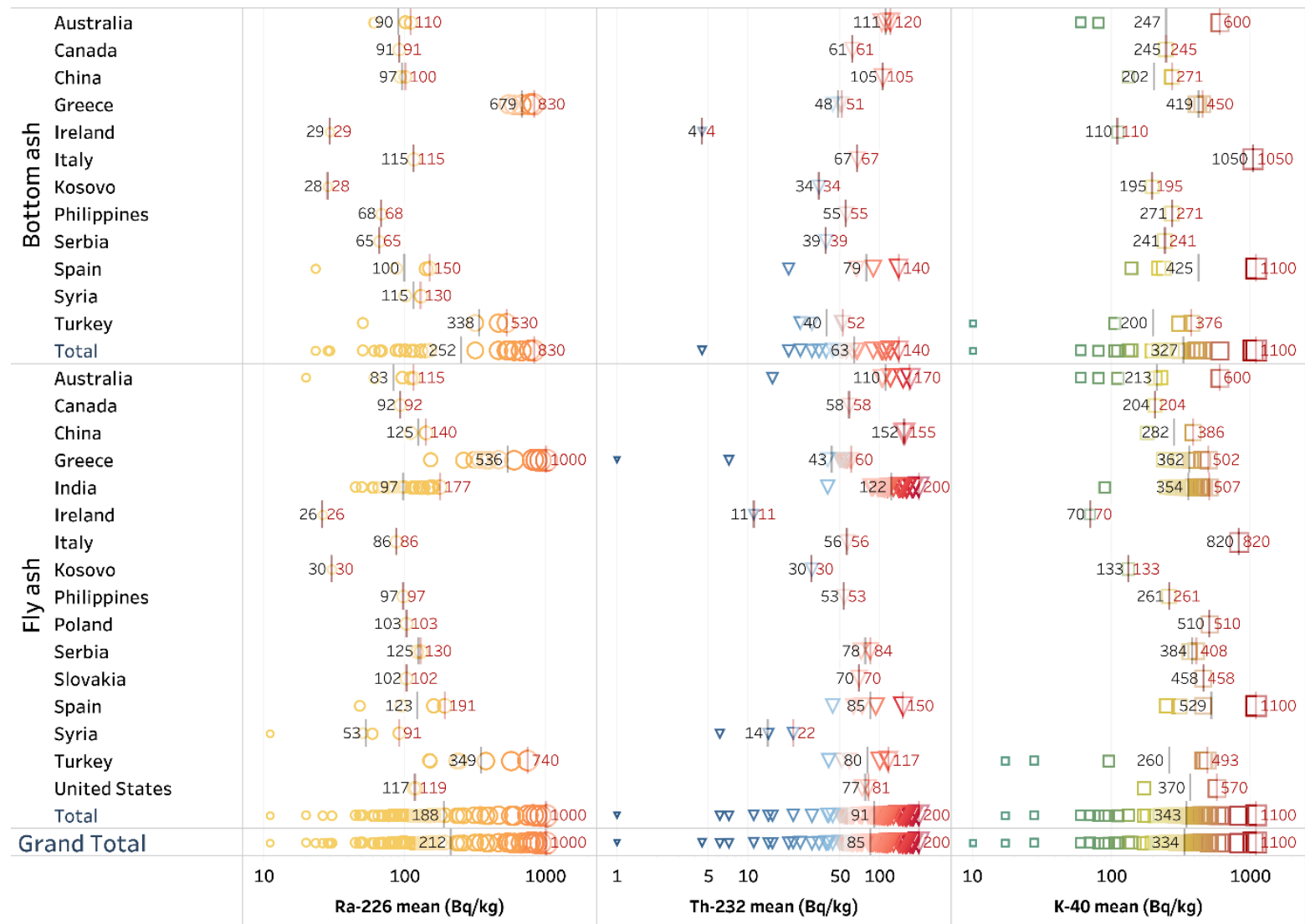

Figure 2 Average reported activity concentrations (logarithmic scale) of ${ }^{226} \mathrm{Ra},{ }^{232} \mathrm{Th}$ and ${ }^{40} \mathrm{~K}$ for bottom and fly ash from different countries. Each circle, triangle or square (for respectively ${ }^{226} \mathrm{Ra},{ }^{232} \mathrm{Th}$ and ${ }^{40} \mathrm{~K}$ ) is linked to a separate entry in the NORM4Building database. The average and maximal activity concentration for a given country are marked with respectively a black and red line (the numerical values are given).

The activity concentrations of combustion products, in particular bottom ash and fly ash, are given for different countries in Figure 2. In most case the considered combustion products are from coal fired power plants but in a very limitted amount of cases the products come from a peat-fired power plant (Ireland, [53]) or from a heavy oil and natural gas fired power plant (Syria, [72]).

For bottom ash, the ${ }^{226} \mathrm{Ra}$ content ranges from 23 (Spain) - 830 (Greece) Bq/kg, 4 (Ireland) 140 (Spain) $\mathrm{Bq} / \mathrm{kg}$ for ${ }^{232} \mathrm{Th}$ and 10 (Turkey) - 1100 (Spain) $\mathrm{Bq} / \mathrm{kg}$ for ${ }^{40} \mathrm{~K}$. For fly ash ash the ranges 11 (Syria) - 1000 (Greece) Bq/kg, 1 (Greece) - 200 (India) Bq/kg and 17 (Turkey) 1100 (Spain) $\mathrm{Bq} / \mathrm{kg}$ are found for respectively ${ }^{226} \mathrm{Ra},{ }^{232} \mathrm{Th}$ and ${ }^{40} \mathrm{~K}$. In the discussion of the results we focus on the comparison of fly ash and bottom ash originating from the same country since otherwise there is a higher likelyhood that the coal (in most of the cases), used to produce 
a given type of fly or bottom ash, originates from different mines and as a result the properties, including the activity concentrations can be quite different. This difference in activity concentrations for a given type of coal can also be observed from the data available on coal in the online version of the NORM4Building database. Only for specific countries (Australia, Canada, China, Greece, Italy, Kosovo, Philippines, Serbia, Spain and Turkey), information is available on both coal fly ash and bottom ash. For these countries the activity concentrations of fly ash is in average a factor 1.2 (for ${ }^{226} \mathrm{Ra}$ ), 1.2 (for ${ }^{232} \mathrm{Th}$ ) and 1.0 (for ${ }^{40} \mathrm{~K}$ ) higher than for bottom ash. Combustion products from Ireland and Syria are not considered in this comparison since here it concerns combustion products from respectively a peat-fired or a heavy oil and natural gas fired power plant. Extrapolation of the gathered data on ${ }^{226} \mathrm{Ra}$ and ${ }^{232} \mathrm{Th}$ to other radionuclides from the ${ }^{238} \mathrm{U}$ and ${ }^{232} \mathrm{Th}$ decay series is not straightforward since typically for fly ash and bottom ash from coal-burning power plants a significant disruption of the secular equilibrium is observed.

\subsection{By-products from ferrous industry}

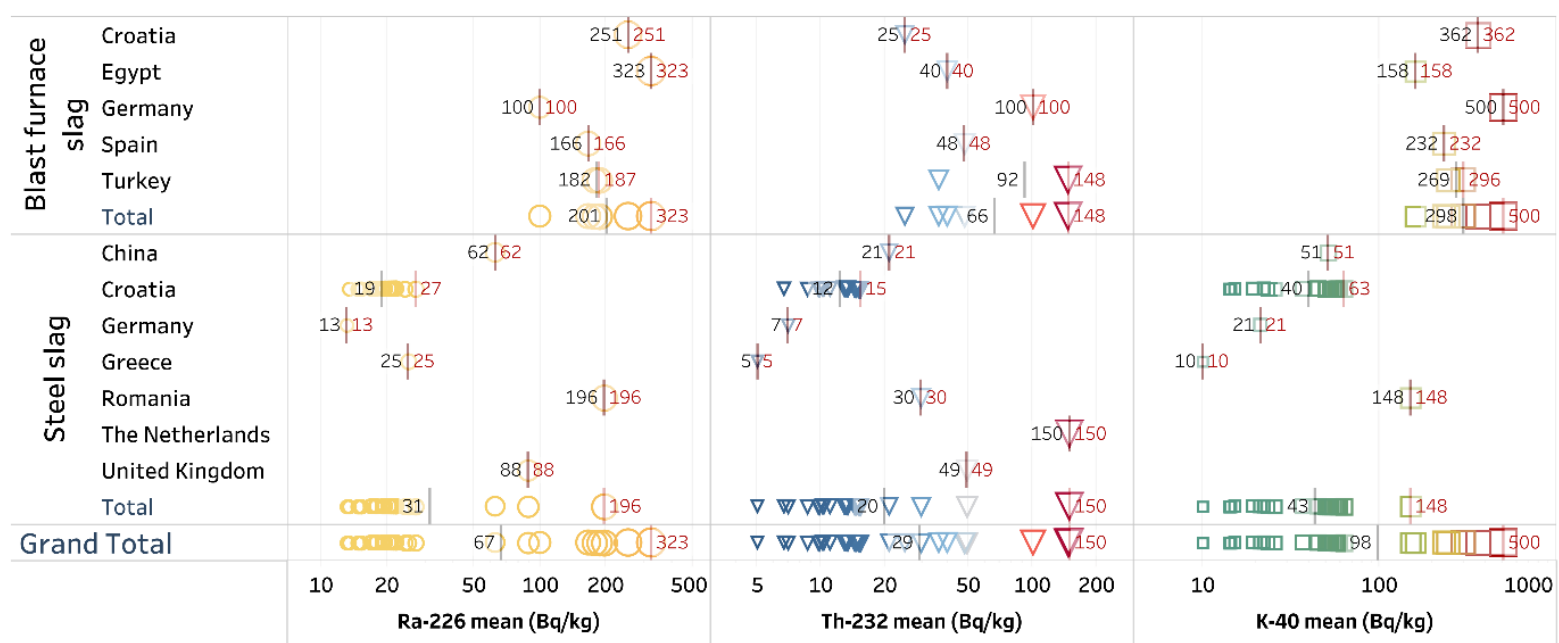

Figure 3 Average reported activity concentrations (logarithmic scale) of ${ }^{226} \mathrm{Ra},{ }^{232} \mathrm{Th}$ and ${ }^{40} \mathrm{~K}$ for blast furnace slag and steel slag from different countries. Each circle, triangle or square (for respectively ${ }^{226} \mathrm{Ra},{ }^{232} \mathrm{Th}$ and ${ }^{40} \mathrm{~K}$ ) is linked to a separate entry in the NORM4Building database. The average and maximal activity concentration for a given country are marked with respectively a black and red line (the numerical values are given).

For the iron ores produced worldwide activity concentration ranges of 5-42 Bq/kg ( $\left.{ }^{226} \mathrm{Ra}\right)$; 2$20 \mathrm{~Bq} / \mathrm{kg}\left({ }^{232} \mathrm{Th}\right)$ and $29-330 \mathrm{~Bq} / \mathrm{kg}\left({ }^{40} \mathrm{~K}\right) \mathrm{can}$ be found in the online NORM4Building database [120]. Starting from the ore, slags are produced in several stages of the production of iron and steel: (1) in the course of the pig iron production; (2) in the blast furnace; (3) in the steel production. The activity concentration of these types of slags produced in several countries is given in Figure 3.

For iron slag only results on blast furnace slag are shown. This specific type of iron slag that contains several impurities that were originally present in the iron (mainly silica and alumina) 
is the most important by-product from iron production that is used in construction. For blast furnace slag, considering the listed European and Middle Eastern countries, the activity concentration show ranges of $100-323 \mathrm{~Bq} / \mathrm{kg}\left({ }^{226} \mathrm{Ra}\right) ; 25-148 \mathrm{~Bq} / \mathrm{kg}\left({ }^{232} \mathrm{Th}\right)$ and $158-500 \mathrm{~Bq} / \mathrm{kg}$ $\left({ }^{40} \mathrm{~K}\right)$ (Figure 3). In average the activity concentration of blast furnace slag is 13,8 and 2 times higher for respectively ${ }^{226} \mathrm{Ra},{ }^{232} \mathrm{Th}$ and ${ }^{40} \mathrm{~K}$ when compared to the average activity concentration of iron ore [120]. This significant difference indicates that the specific production process that leads to a given type of iron slag has a dominant impact on the radiological properties which is also reported by Puch et al. [121].

For steel slag the following activity concentration ranges are found: $9-196 \mathrm{~Bq} / \mathrm{kg}\left({ }^{226} \mathrm{Ra}\right)$; 4-150 $\mathrm{Bq} / \mathrm{kg}\left({ }^{232} \mathrm{Th}\right)$ and $5-148 \mathrm{~Bq} / \mathrm{kg}\left({ }^{40} \mathrm{~K}\right)$. In this case, when comparing steel slag to iron ore, the world average activity concentrations are only a factor 2 higher for ${ }^{226} \mathrm{Ra}$ and ${ }^{232} \mathrm{Th}$, while for ${ }^{40} \mathrm{~K}$ the activity concentration is in this case a factor 3 lower. When comparing the activity concentration of steel slag to blast furnace slag for the same country (Croatia and Germany) the the activity concentration of blast furnace slag is in average a factor 10.5 (for ${ }^{226} \mathrm{Ra}$ ); 8.1 (for ${ }^{232} \mathrm{Th}$ ) and 16.5 (for ${ }^{40} \mathrm{~K}$ ) higher than for steel slag.

\subsection{By-products from non-ferrous industry}

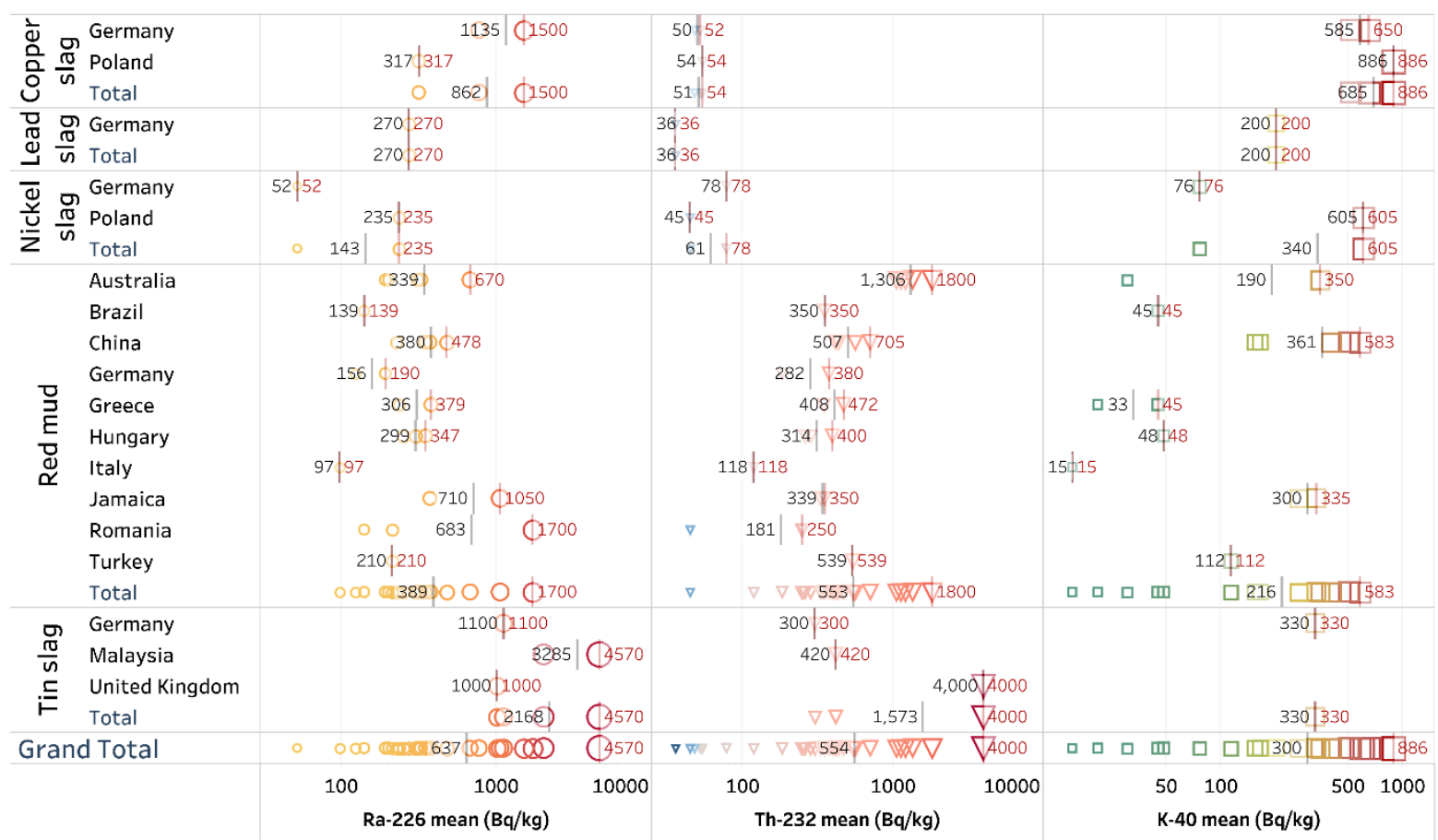

Figure 4 Average reported activity concentrations (logarithmic scale) of ${ }^{226} \mathrm{Ra},{ }^{232} \mathrm{Th}$ and ${ }^{40} \mathrm{~K}$ for nickel, copper, lead and tin slag and red mud from different countries. Each circle, triangle or square (for respectively ${ }^{226} \mathrm{Ra},{ }^{232} \mathrm{Th}$ and ${ }^{40} \mathrm{~K}$ ) is linked to a separate entry in the NORM4Building database. The average and maximal activity concentration for a given country are marked with respectively a black and red line (the numerical values are given).

Processes in the non-ferrous industry can be complicated, and several metals can be extracted from a given type of primary or secondary raw material or a combination of materials leading 
to various types of slags and therefore it is not straightforward to compare general ore related information to a specific type of slag. In the current section, we discuss properties of several types of non-ferrous residues, however it is mainly for red mud and copper slag that reuse in cement and/or concrete is a realistic option.

For red mud, a by-product of Bayer method to process bauxite ore, average activity concentrations ranging from 97 (Italy) to 1700 (Romania) Bq/kg ${ }^{226} \mathrm{Ra} ; 45$ (Romania) to 1800 (Australia) $\mathrm{Bq} / \mathrm{kg}^{232} \mathrm{Th}$ and 15 (Italy) to 583 (China) $\mathrm{Bq} / \mathrm{kg}^{40} \mathrm{~K}$ are found (Figure 4). In average the total average activity concentrations of red mud are only a factor 1.3 (for ${ }^{226} \mathrm{Ra}$ ); 1.8 (for ${ }^{232} \mathrm{Th}$ ) and 5.5 (for ${ }^{40} \mathrm{~K}$ ) higher than for bauxite [120].

For tin and copper slag, the average activity concentrations are relatively high: up to $4570 \mathrm{~Bq} / \mathrm{kg}$ ${ }^{226} \mathrm{Ra}$ for Malaysian tin slag, up to $4000 \mathrm{~Bq} / \mathrm{kg}{ }^{232} \mathrm{Th}$ for tin slag from the UK and up to 1500 $\mathrm{Bq} / \mathrm{kg}{ }^{226} \mathrm{Ra}$ for German copper slag (Figure 4). For lead slag (up to $270 \mathrm{~Bq} / \mathrm{kg}$ for Germany) and nickel slag (up to $235 \mathrm{~Bq} / \mathrm{kg}$ for Poland), the listed values are apparently lower, but no data was collected from outside Europe. It has to be noted that the database contains mainly data for slags from primary melters. As published by Croymans et al. [122] the activity concentrations of the slags of a secondary melter for the production of tin, copper and other types of metals that also involve secundary raw materials are significantly lower.

With the datamining tool we aim to step by step get a more detailled view on different types of slag. This requires expanding the key-words used for specific types of ferrous and non-ferrous slag and getting access to country specific information that is not always accessible online.

\subsection{Construction industry}

\subsubsection{Cement}




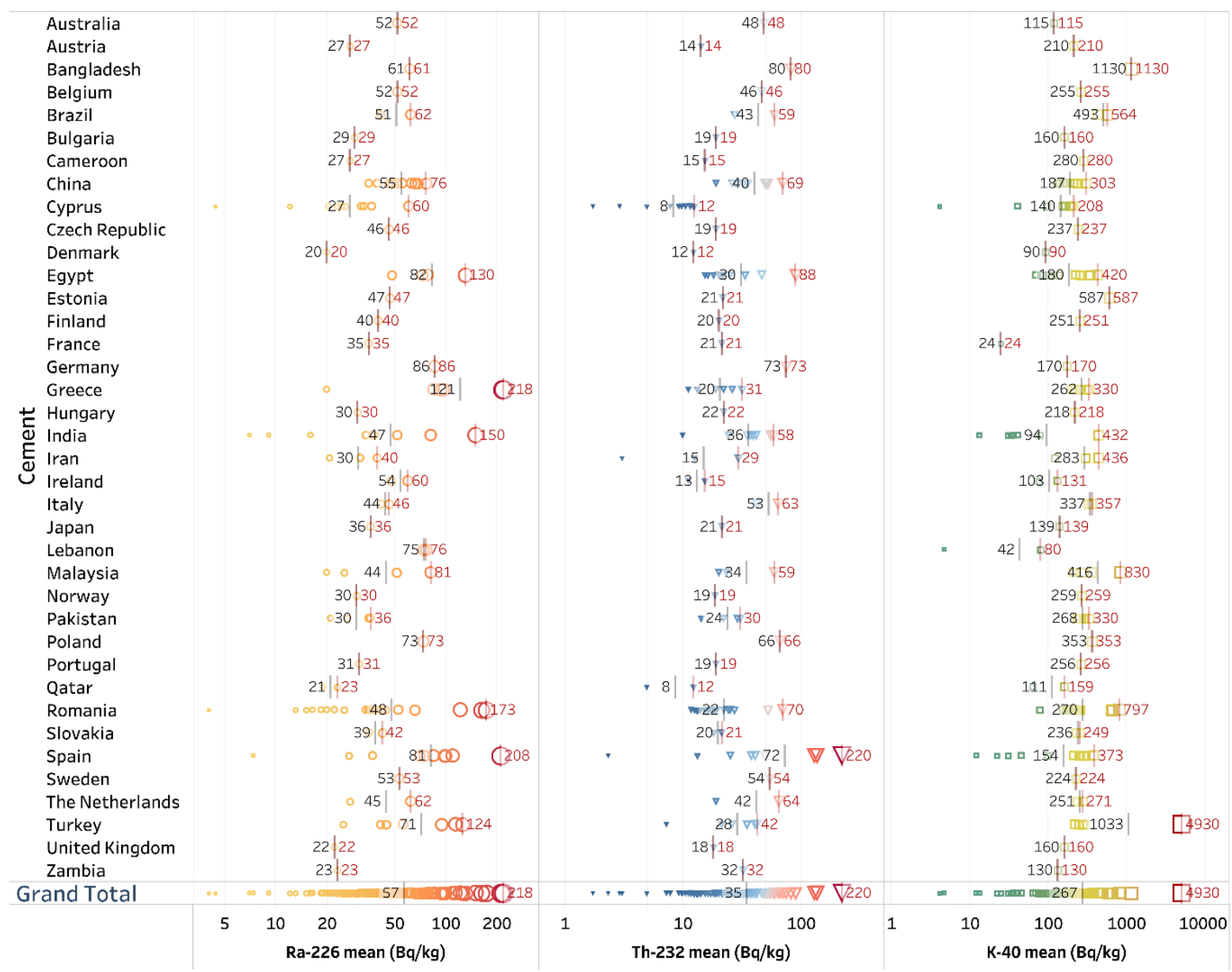

Figure 5 Average reported activity concentrations (logarithmic scale) of ${ }^{226} \mathrm{Ra},{ }^{232} \mathrm{Th}$ and ${ }^{40} \mathrm{~K}$ for cement in different countries. Each circle, triangle or square (for respectively ${ }^{226} \mathrm{Ra},{ }^{232} \mathrm{Th}$ and ${ }^{40} \mathrm{~K}$ ) is linked to a separate entry in the NORM4Building database. The average and maximal activity concentration for a given country are marked with respectively a black and red line (the numerical values are given).

For cement, the following ranges of activity concentrations can be extracted from Figure 5: 4 (Romania) - 218 (Greece) Bq/kg for ${ }^{226} \mathrm{Ra} ; 2$ (Cyprus) - 220 (Spain) Bq/kg for ${ }^{232} \mathrm{Th}$ and 4 (Cyprus) -4930 (Turkey) $\mathrm{Bq} / \mathrm{kg}$ for ${ }^{40} \mathrm{~K}$. For cement world wide average activity concentrations of $54 \mathrm{~Bq} / \mathrm{kg}{ }^{226} \mathrm{Ra} ; 33 \mathrm{~Bq} / \mathrm{kg}{ }^{232} \mathrm{Th}$ and $257 \mathrm{~Bq} / \mathrm{kg}{ }^{40} \mathrm{~K}$ are found. It needs to be noted that the database contains information on a lot of different types of cement. Among others information on cement types CEM I, II, III, IV and V is included, but this information is not always clearly provided in the included papers. Assisted by the datamining approach it is the aim to modifiy the keywords in such a way that also a distinction can be made between different types of cement. 


\subsubsection{Building materials}

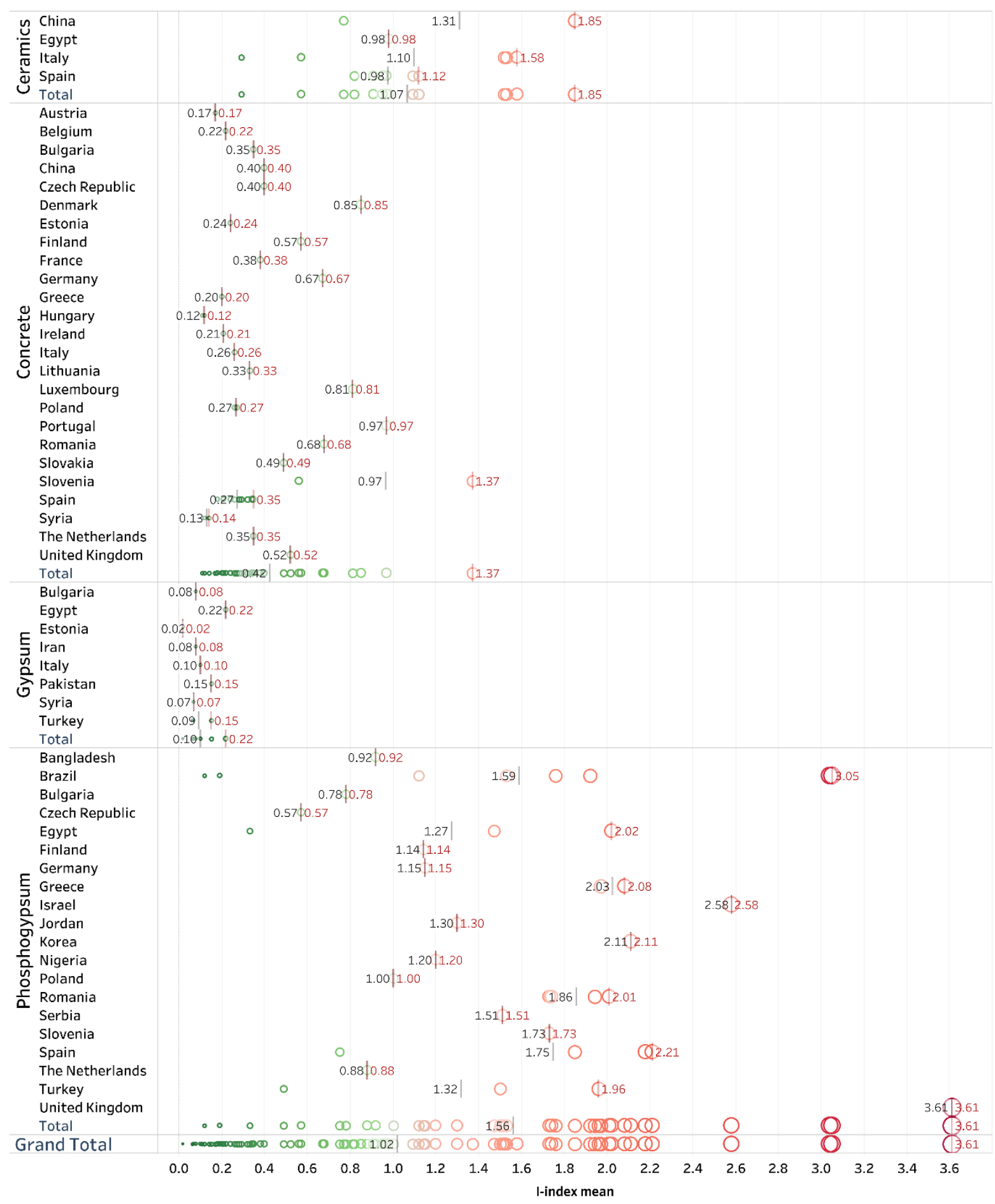

Figure 6 I-index (calculated from average reported activity concentrations) for building materials in different countries. Each circle is linked to a separate entry in the NORM4Building database. The average and maximal activity concentration for a given country are marked with respectively a black and red line (the numerical values are given).

For ceramics, only a limited amount of data is gathered since this was so far not the in the focus of the datamining process. Even for the limited amount of data gathered a large range in the calculated I-index was found: 0.29 (Italy) - 1.85 (China) (Figure 6). The broad distribution in Figure 6 reflects a broad range of different materials, but the discussion of these materials falls out of the scope of the current paper. More information on the use of by-products (in particular 
zircon and zirconia) in ceramics and the radiological properties of the resulting ceramics is proposed by Selby [123].

Clearly visualised in Figure 6 is the large difference between the I-index distribution of gypsum (hydrous calcium sulfate), this category involves both natural gypsum stone (anhydriteanhydrous calcium sulfate) and synthetic gypsum (anhydrite), and phosphogypsum. For gypsum, the I-index values range from 0.02 (Estonia) to 0.22 (Egypt), and a mean worldwide average I-index of 0.11 is found, while for phosphogypsum an I-index range of 0.12 (Brasil) to 3.61 (United Kingdom) and a mean worldwide average I-index of 1.56 is found. The radiological issues regarding the use of phosphogypsum in construction are discussed in more detail in [12].

For concrete, the I-index values range from 0.11 (Hungary) to 1.37 (Slovenia) and a worldwide average I-index value of 0.37 is found which is comparable to an average value for reference concrete of 0.41 assuming scenario ID 1 from Table 2.

\subsubsection{Simulating the use of by-products in building materials}

In the current section, realistic scenarios for concretes incorporating different types of byproducts - as described in Table 2 - are discussed in more detail. The discussion is limited to by-products that are considered for use in building materials, for the construction of buildings because it is for this situation that the EU-BSS applies. Therefore, for example, coal bottom ash and coal slag, that primarily find use as an artificial aggregate/additive in road or country road construction [124] [125] are not considered here. The I-index of a given by-product is given purely for comparison and calculation purposes. Providing an I-index for a by-product makes the unrealistic assumption that $100 \%$ of the by-product is used as a building material, while in the actual assessment the proper partition factor has to be considered.

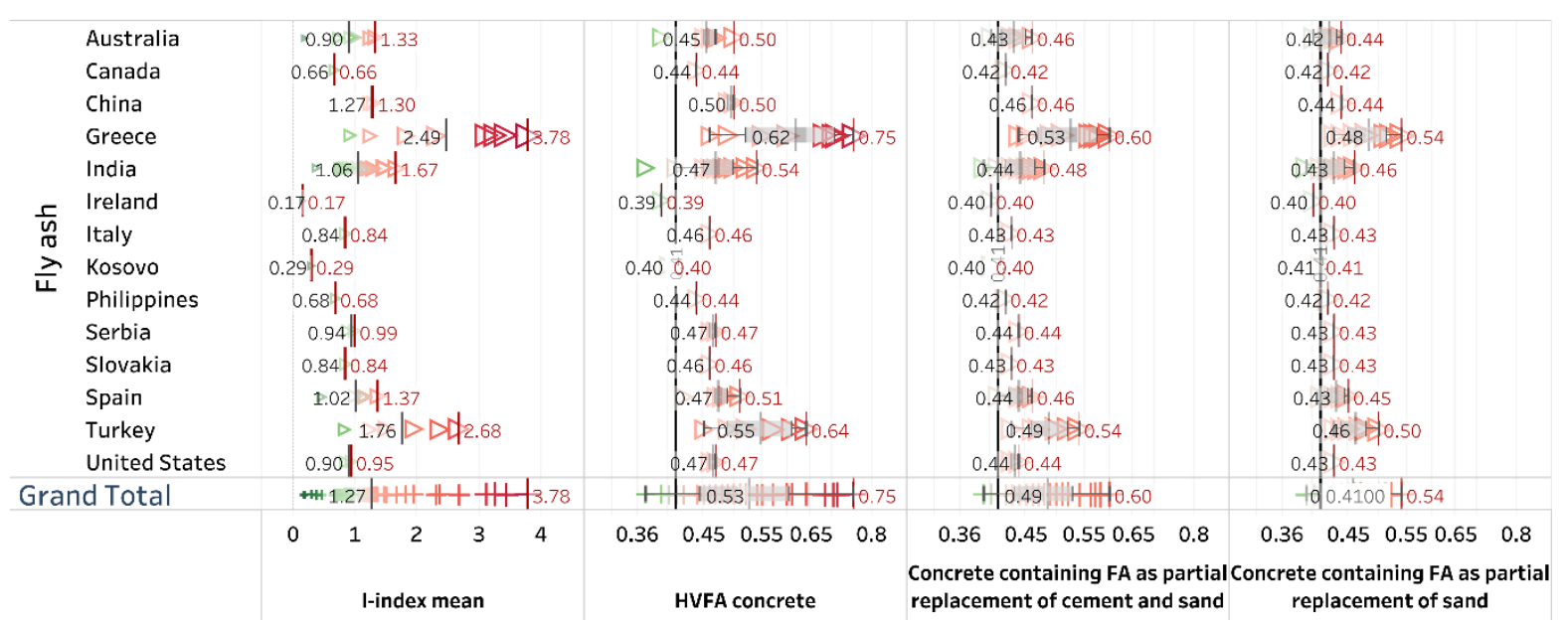


Coal fly ash is a well-known cement constituent and concrete additive [126]: fly ash can be used in the cement production as the material to produce Portland clinker and as a mineral or pozzolana addition. Including fly ash in blended cement has benificial properties for concrete [127] [128]. The highest content of fly ash in concrete is obtained in high-volume fly ash concrete (HVFA): in the described scenario (ID 2) $40 \mathrm{~kg} / \mathrm{m}^{3}$ of cement and $180 \mathrm{~kg} / \mathrm{m}^{3}$ of aggregates/sand is replaced by FA, and this leads in general to a lower water demand (140 $\mathrm{kg} / \mathrm{m}^{3}$ in ID 2) of the concrete for a given workability. Even for HVFA concrete, the simulated I-indexes are below 1 (Figure 7). The largest I-index was 0.75 (Greece). For concretes containing FA as a partial replacement of sand and/or aggregates (ID 3 and ID 4) the I-index is around the value of reference concrete $(0,41)$.

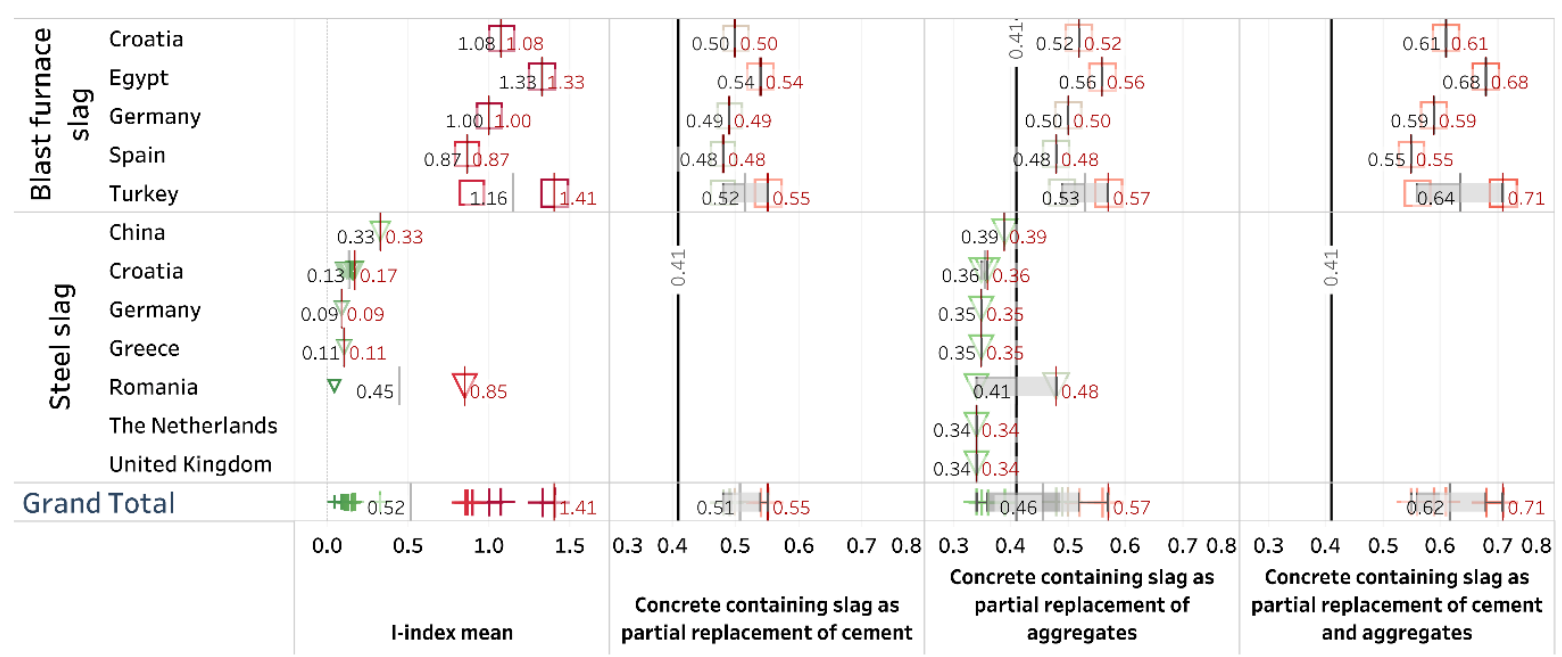

Figure 8 Calculated values of the I-index for ferrous slag, concrete containing ferrous as partial replacement of cement and/or aggregates.

When considering the slags from iron and steel production, ground-granulated blast furnace slag is by far the main by-product that finds its way in construction as a well-known cement constituent and concrete additive. As shown in Figure 8, the I-index reaches maximal values of 0.55, 0.57 and 0.71 when blast furnace slag (from Turkey) is used as a replacement for respectively cement (ID 6), aggregate (ID 7) or both (ID 5).

For steel slag only a replacement of the aggregates is considered as a realistic scenario ([12]. Steel slag is commonly blended with ground-granulated blast furnace slag, coal fly ash and lime for the production of pavement material, skid resistant asphalt aggregate and unconfined construction fill. In this case, the I-index is around the value of reference concrete in the unlikely case that steel slag is used for buildings (ID 7). 


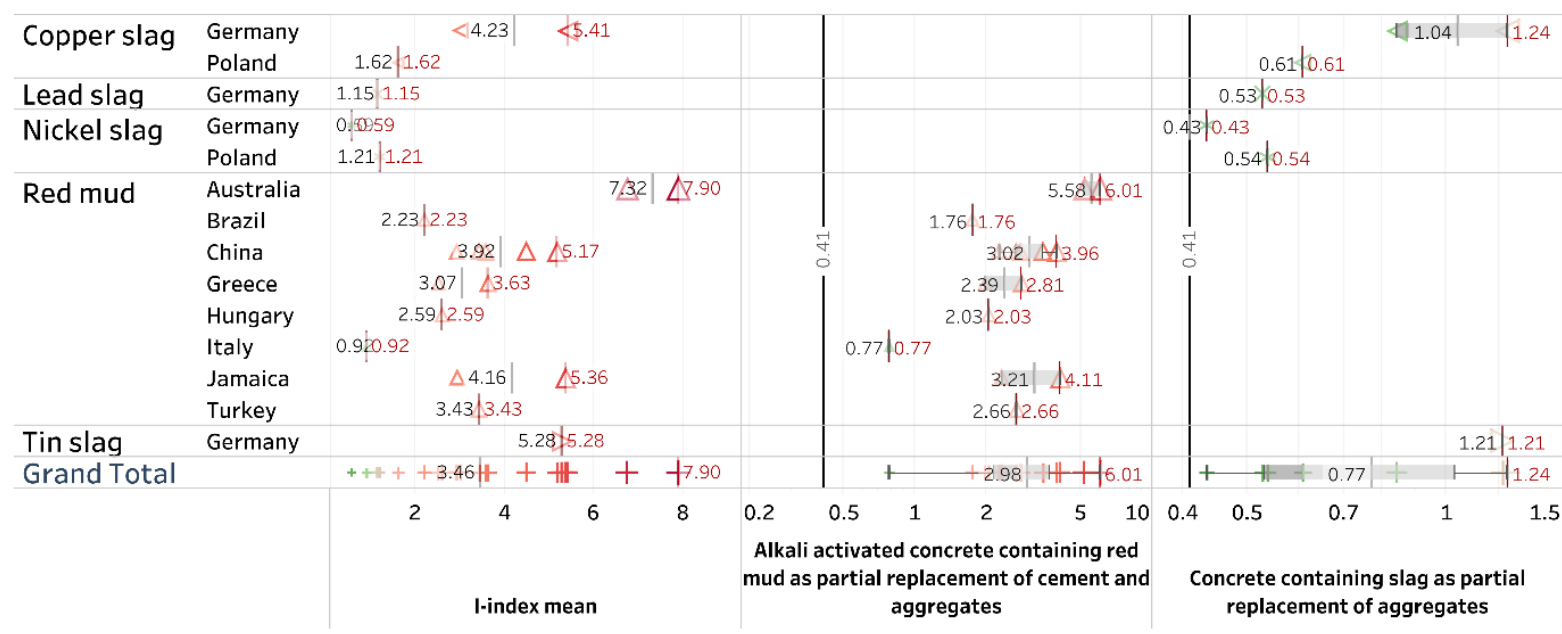

Figure 9 Calculated values of the I-index for non-ferrous slag and red mud, concrete containing non-ferrous slag as partial replacement of aggregates and alkali activated concrete containing red mud as partial replacement of cement and aggregates.

In the description of the non-ferrous slags (Figure 9) mainly scenario ID 7 is considered where non-ferrous slag serve as a replacement for (fine) aggregates in concretes. In principle, granulated copper slag exhibits pozzolanic properties which also allow the use as a constituent for common Portland cement but then the impact on the activity concentration is small, and this scenario is not further discussed [129]. The composition and characteristics of a specific type of copper, lead, nickel or tin slag determine its possible application. The application as (fine) aggregate in concrete for use in a building is very much dependent on the specific properties of a given type of slag. Upon using German tin and copper slag as a partial replacement for aggregates in concrete, the I-index can be above 1: respectively 1.21 and 1.24 so, in this case, further studies are required to assess the gamma dose upon reuse. For lead and nickel slag the found I indexes are lower, around 0.5.

It is unlikely that red mud will be used as aggregate in Portland concrete since this requires several processing steps, including drying, pelletizing and calcinations that will significantly increase the processing cost respect to other types of aggregates. A more realistic scenario, discussed by Croymans et al. [130], is the use of red mud in alkali-activated cement and concrete (ID 8). In alkali-activated concrete, a relatively high incorporation level of red mud $\left(1800 \mathrm{~kg} / \mathrm{m}^{3}\right.$ red mud for a total of $2400 \mathrm{~kg} / \mathrm{m}^{3}$ concrete) can be achieved for concrete resulting in an I-index that can be around 6.01 (Australia). A more detailed dose assessment is then required to investigate which incorporation level can be acceptable considering the EU-BSS.

\section{Conclusions}

Publications have been processed from different electronic sources by means of a semiautomated data mining tool to extract data on NORM in ores, by-products and construction materials. After careful manual revision a total number of 1422 entries on different types of materials from all together 74 countries worldwide were accepted for the NORM4Building database (date: 01/07/2017). By using the technique of datamining the NORM4Building 
database can, after manual revision, be updated in the future. When the datamining tool is working, the number of investigated publications increases by the hundreds monthly or more. The advantages of this approach consists in the capability to identify and analyse data reported in tables and grammatically complete definitions quickly and reliably. The limitation of this approach is that data from graphical images (eg.: histograms) are currently not collected and that a manual verification is required to avoid that data overlaps and to evaluate the reliability of the included data. Based on the data gathered, data mining also allows to revise our selection criteria and in this way step by step a more detailed database can be built where a more detailed investigation of sub-population (different types of slags, combustion products, cements, concretes...) becomes possible.

In this paper a limited dataset (460 entries) from the NORM4Building database is shown and discussed. Specific by-products from industries involving NORM that have suitable properties for use in concrete for buildings were selected for evaluation. For the evaluation 7 different scenarios for by-product incorporation in concrete were considered. In addition, also the radiological properties of cement and other construction materials such as ceramics and (phospho)gypsum were discussed. Considering the criteria set by the EU-BSS and based on the data gathered in the NORM4Building database in particular non-ferrous slags and red mud require a radiological evaluation before the use in concrete for buildings can be accepted. For the considered residues of the ferrous industry the reported activity concentrations are significantly lower and the impact, from a radiological perspective is less pronounced.

\section{Acknowledgement}

The authors would like to acknowledge networking support by the COST Action TU1301. www.norm4building.org. The authors wish to thank the University of Pannonia for the management and setting up of the database and datamining approach. In addition, the authors would like to thank all the colleagues who helped creating and evaluating the database and are very grateful to University of Hasselt for support on accessing the e-Journals. This work was supported by the European Union's Horizon 2020 research and innovation programme under the Marie Sklodowska-Curie grant agreement No 701932.

\section{References}

[1] European Commision, An EU action plan for the circular economy, Com. 614 (2015) 21. doi:10.1017/CBO9781107415324.004.

[2] European Parliament and Council, Directive 2008/98/EC of the European Parliament and of the Council of 19 November 2008 on waste and repealing certain directives, 2008. doi:2008/98/EC.; 32008L0098.

[3] European Parliament, Council Directive 2013/59/Euratom of 5 December 2013 laying down basic safety standards for protection against the dangers arising from exposure to ionising radiation, and repealing Directives 89/618/Euratom, 90/641/Euratom, 
96/29/Euratom, 97/43/Euratom a, Off J Eur Commun L13. (2014) 1-73.

doi:10.3000/19770677.L_2013.124.eng.

[4] IAEA Publications, Radiation Protection and Safety of Radiation Sources: International Basic Safety Standards., (2014). doi:STI/PUB/1578.

[5] ICRP, The 2007 Recommendations of the International Commission on Radiological Protection. ICRP Publication 103. Ann. ICRP 37 (2-4), 2007.

doi:10.1016/j.icrp.2007.10.003.

[6] UNSCEAR, Sources and Effects of Ionizing Radiation: Sources Annex B. Exposures of the Public and Workers from Various Sources of Radiation, 2008.

[7] R. Trevisi, S. Risica, M. D’Alessandro, D. Paradiso, C. Nuccetelli, Natural radioactivity in building materials in the European Union: A database and an estimate of radiological significance, J. Environ. Radioact. 105 (2012) 11-20.

doi:10.1016/j.jenvrad.2011.10.001.

[8] Z. Sas, R. Doherty, T. Kovacs, M. Soutsos, W. Sha, W. Schroeyers, Radiological evaluation of by-products used in construction and alternative applications; Part I. Preparation of a natural radioactivity database, Constr. Build. Mater. 150 (2017) 227237. doi:10.1016/j.conbuildmat.2017.05.167.

[9] National Institute of Radiological Sciences, NORM Database: NIRS, (n.d.).

[10] F.J. Maringer, P. De Felice, V. Peyres, M.T. Crespo, E. García-toraño, MetroNORM Metrology for processing materials with high natural radioactivity, (2013).

[11] M.J. Zaki, W. Meira, Data Mining and Analysis: Fundamental Concepts and Algorithms, 2014.

[12] Cost network NORM4Building, Naturally Occurring Radioactive Materials in Construction, 2017. https://www.elsevier.com/books/naturally-occurring-radioactivematerials-in-construction/schroeyers/978-0-08-102009-8.

[13] A. Eštoková, L. Palaščáková, Assessment of natural radioactivity levels of cements and cement composites in the Slovak Republic., Int. J. Environ. Res. Public Health. 10 (2013) 7165-7179. doi:10.3390/ijerph10127165.

[14] N. Ibrahim, Natural activities of $238 \mathrm{U}, 232 \mathrm{Th}$ and $40 \mathrm{~K}$ in building materials, J. Environ. Radioact. 43 (1999) 255-258. doi:10.1016/S1350-4487(03)00173-2.

[15] M.S. Yasir, A. Ab Majid, R. Yahaya, Study of natural radionuclides and its radiation hazard index in Malaysian building materials, J. Radioanal. Nucl. Chem. 273 (2007) 539-541. doi:10.1007/s10967-007-0905-7.

[16] T. Sofilić, D. Barišić, U. Sofilić, Monitoring of 137Cs in electric arc furnace steel making process, J. Radioanal. Nucl. Chem. 284 (2010) 615-622. doi:10.1007/s10967010-0513-9.

[17] T. Sofilić, D. Barišić, A. Rastovčan Mioč, U. Sofilić, Radionuclides in steel slag intended for road construction, J. Radioanal. Nucl. Chem. 284 (2010) 73-77. doi:10.1007/s10967-009-0431-X.

[18] R. Lehmann, Strahlenbelastung durch natürliche radionuklide in baumaterialien, fossilen brennstoffen und Dungemitteln, Bundesamt Für Strahlenshutz, Berlin. (1996) $135-156$.

[19] F. Gezer, Ş. Turhan, F.A. Uğur, E. Gören, M.Z. Kurt, Y. Ufuktepe, Natural radionuclide content of disposed phosphogypsum as TENORM produced from phosphorus fertilizer industry in Turkey, Ann. Nucl. Energy. 50 (2012) 33-37. doi:10.1016/j.anucene.2012.07.018.

[20] C. Potiriadis, V. Koukouliou, S. Seferlis, K. Kehagia, Assessment of the occupational exposure at a fertiliser industry in the northern part of Greece, Radiat. Prot. Dosimetry. 144 (2011) 668-671. doi:10.1093/rpd/ncq309.

[21] M. Sharaf, M. Mansy, A. El Sayed, E. Abbas, Natural radioactivity and radon exhalation rates in building materials used in Egypt, Radiat. Meas. 31 (1999) 491-495. doi:10.1016/S1350-4487(99)00206-1.

[22] F. Malik, M.A. Matiullah, M.U. Rajput, Measurement of natural radioactivity in sand samples collected along the bank of rivers Indus and Kabul in northern Pakistan, Radiat. Prot. Dosimetry. 143 (2011) 97-105. doi:10.1093/rpd/ncq356.

[23] S.A. Mujahid, A. Rahim, S. Hussain, M. Farooq, Measurements of natural radioactivity 
and radon exhalation rates from different brands of cement used in Pakistan, Radiat. Prot. Dosimetry. 130 (2007) 206-212. doi:10.1093/rpd/ncm497.

[24] J.H. Zaidi, M. Arif, I. Fatima, Determination of natural radioactivity in building materials used in the Karachi area by $\gamma$-ray spectrometry and INAA, Radiochim. Acta. 92 (2004) 945-949. doi:10.1524/ract.92.12.945.55107.

[25] A. Zak, K. Isajenko, B. Piotrowska, M. Kuczbajska, A. Zabek, T. Szczygielski, Natural radioactivity of wastes, Nukleonika. 55 (2010) 387-391.

[26] P.P. Haridasan, P.M.B. Pillai, R.M. Tripathi, V.D. Puranik, An evaluation of radiation exposures in a tropical phosphogypsum disposal environment, Radiat. Prot. Dosimetry. 135 (2009) 211-215. doi:10.1093/rpd/ncp098.

[27] C. Nuccetelli, Y. Pontikes, F. Leonardi, R. Trevisi, New perspectives and issues arising from the introduction of (NORM) residues in building materials: A critical assessment on the radiological behaviour, Constr. Build. Mater. 82 (2015) 323-331. doi:10.1016/j.conbuildmat.2015.01.069.

[28] N. Fathabadi, M.V. Farahani, M. Moradi, B. Hadadi, Estimates of the occupational exposure to tenorm in the phosphoric acid production plant in Iran, Radiat. Prot. Dosimetry. 151 (2012) 600-603. doi:10.1093/rpd/ncs021.

[29] S. Chinchón-Payá, B. Piedecausa, S. Hurtado, M.A. Sanjuán, S. Chinchón, Radiological impact of cement, concrete and admixtures in Spain, Radiat. Meas. 46 (2011) 734-735. doi:10.1016/j.radmeas.2011.06.020.

[30] J. Beretka, P.J. Mathew, Natural Radioactivity of Australian Building Materials, Industrial Wastes and By-products, Health Phys. 48 (1985) 87-95. doi:10.1097/00004032-198501000-00007.

[31] H. Baltas, E. Kiris, I. Ustabas, E. Yilmaz, M. Sirin, E. Kuloglu, B.E. Gunes, Determination of Natural Radioactivity Levels of Some Concretes and Mineral Admixtures in Turkey, Asian J. Chem. 26 (2014) 3946-3952. doi:10.14233/ajchem.2014.16045.

[32] Ş. Turhan, Assessment of the natural radioactivity and radiological hazards in Turkish cement and its raw materials, J. Environ. Radioact. 99 (2008) 404-414. doi:10.1016/j.jenvrad.2007.11.001.

[33] H. Al-Sulaiti, N. Alkhomashi, N. Al-Dahan, M. Al-Dosari, D.A. Bradley, S. Bukhari, M. Matthews, P.H. Regan, T. Santawamaitre, Determination of the natural radioactivity in Qatarian building materials using high-resolution gamma-ray spectrometry, in: 2011. doi:10.1016/j.nima.2011.01.020.

[34] B.L. Tracy, F.A. Prantl, Radiological impact of coal-fired power generation, J. Environ. Radioact. 2 (1985) 145-160. doi:10.1016/0265-931X(85)90004-9.

[35] J. Al-Jundi, N. Al-Ahmad, H. Shehadeh, F. Afaneh, M. Maghrabi, U. Gerstmann, V. Höllriegl, U. Oeh, Investigations on the activity concentrations of 238U, 226RA, 228RA, 210 PB and 40K in Jordan phosphogypsum and fertilizers, Radiat. Prot. Dosimetry. 131 (2008) 449-454. doi:10.1093/rpd/ncn214.

[36] A. Pantelica, Georgescu II, M.D. Murariu-Magureanu, I. Margaritescu, E. Cincu, Thorium determination in intercomparison samples and in some Romanian building materials by gamma ray spectrometry, Radiat Prot Dosim. 97 (2001) 187-191.

[37] L.E. Muntean, C. Cosma, D. V Moldovan, Measurement of natural radioactivity and radiation hazards for some natural and artificial building materials available in Romania, J. Radioanal. Nucl. Chem. 299 (2014) 523-532. doi:10.1007/s10967-0132837-8.

[38] X. Lu, X. Jia, F. Wang, Natural radioactivity of coal and its by-products in the Baoji coal-fired power plant, China, Curr. Sci. 91 (2006) 1508-1511.

[39] M.W. Tso, J.K.C. Leung, Radiological impact of coal ash from the power plants in Hong Kong, J. Environ. Radioact. 30 (1996) 1-14. doi:10.1016/0265-931X(95)000429.

[40] M.B. Cooper, Naturally Occurring Radioactive Materials ( NORM ) in Australian Industries - Review of Current Inventories and Future Generation, 2005.

[41] M. Vladar, H. Cabanekova, Natural Radioactivity in Slovak Construction Materials and the Indoors Dose Rate From Building Materials, in: Conf. Proc. 21-St Radiat. Hyg. 
Days, 1998.

[42] M. Manolopoulou, C. Papastefanou, Behavior of natural radionuclides in lignites and fly ashes, J. Environ. Radioact. 16 (1992) 261-271. doi:10.1016/0265-931X(92)90005E.

[43] C. Papastefanou, S. Charalambous, Hazards from Radioactivity of Fly Ash of Greek Coal Power Plants (CPP), Pergamon Press. I (1980) 153-158.

[44] C. Papastefanou, Escaping radioactivity from coal-fired power plants (CPPs) due to coal burning and the associated hazards: A review, J. Environ. Radioact. 101 (2010) 191-200. doi:10.1016/j.jenvrad.2009.11.006.

[45] S.E. Simopoulos, M.G. Angelopoulos, Natural radioactivity releases from lignite power plants in Greece, J. Environ. Radioact. 5 (1987) 379-389. doi:10.1016/0265931X(87)90012-9.

[46] H. Papaefthymiou, B.D. Symeopoulos, M. Soupioni, Neutron activation analysis and natural radioactivity measurements of lignite and ashes from Megalopolis basin, Greece, J. Radioanal. Nucl. Chem. 274 (2007) 123-130. doi:10.1007/s10967-0066880-6.

[47] G. Xhixha, G.P. Bezzon, C. Broggini, G.P. Buso, A. Caciolli, I. Callegari, S. De Bianchi, G. Fiorentini, E. Guastaldi, M. Kaçeli Xhixha, F. Mantovani, G. Massa, R. Menegazzo, L. Mou, A. Pasquini, C.R. Alvarez, M. Shyti, The worldwide NORM production and a fully automated gamma-ray spectrometer for their characterization, J. Radioanal. Nucl. Chem. 295 (2013) 445-457. doi:10.1007/s10967-012-1791-1.

[48] V. Kumar, T. V. Ramachandran, R. Prasad, Natural radioactivity of Indian building materials and by-products, Appl. Radiat. Isot. 51 (1999) 93-96. doi:10.1016/S09698043(98)00154-7.

[49] M. Gupta, A.K. Mahur, R. Varshney, R.G. Sonkawade, K.D. Verma, R. Prasad, Measurement of natural radioactivity and radon exhalation rate in fly ash samples from a thermal power plant and estimation of radiation doses, Radiat. Meas. 50 (2013) 160165. doi:10.1016/j.radmeas.2012.03.015.

[50] A.K. Mahur, R. Kumar, M. Mishra, D. Sengupta, R. Prasad, An investigation of radon exhalation rate and estimation of radiation doses in coal and fly ash samples, Appl. Radiat. Isot. 66 (2008) 401-406. doi:10.1016/j.apradiso.2007.10.006.

[51] K. Kant, Rashmi, S. Kuriakose, R.G. Sonkawade, R.P. Chauhan, S.K. Chakarvarti, G.S. Sharma, Radon activity and exhalation rates in Indian fly ash samples, Indian J. Pure Appl. Phys. 48 (2010) 457-462.

[52] M.C. Okeji, K.K. Agwu, F.U. Idigo, Assessment of natural radioactivity in phosphate ore, phosphogypsum and soil samples around a phosphate fertilizer plant in Nigeria, Bull. Environ. Contam. Toxicol. 89 (2012) 1078-1081. doi:10.1007/s00128-012-08118.

[53] C. Organo, E.M. Lee, G. Menezes, E.C. Finch, Investigation of occupational radiation exposures to NORM at an Irish peat-fired power station and potential use of peat fly ash by the construction industry., J. Radiol. Prot. 25 (2005) 461-474. doi:10.1088/0952-4746/25/4/008.

[54] M. Zieliński, Influence of constant magnetic field on the properties of waste phosphogypsum and fly ash composites, Constr. Build. Mater. 89 (2015) 13-24. doi:10.1016/j.conbuildmat.2015.04.029.

[55] F. Hasani, F. Shala, G. Xhixha, M.K. Xhixha, G. Hodolli, S. Kadiri, E. Bylyku, F. Cfarku, Naturally occurring radioactive materials (NORMs) generated from lignitefired power plants in Kosovo, J. Environ. Radioact. 138 (2014) 156-161. doi:10.1016/j.jenvrad.2014.08.015.

[56] J.G. Ackers, J.F. Den Boer, P. De Jong, R.A. Wolschrijn, Radioactivity and radon exhalation rates of building materials in The Netherlands, Sci. Total Environ. 45 (1985) 151-156. doi:10.1016/0048-9697(85)90215-3.

[57] M.R. Calin, I. Radulescu, M.A. Calin, Measurement and evaluation of natural radioactivity in phosphogypsum in industrial areas from Romania, J. Radioanal. Nucl. Chem. 304 (2015) 1303-1312. doi:10.1007/s10967-015-3970-3.

[58] Ş. Turhan, İ.H. Arıkan, A. Köse, A. Varinlioğlu, Assessment of the radiological 
impacts of utilizing coal combustion fly ash as main constituent in the production of cement, Environ. Monit. Assess. 177 (2011) 555-561. doi:10.1007/s 10661-010-16564.

[59] F.S. Erees, S.A. Dayanıklı, S. Çam, Natural Radionuclides in the Building Materials used in Manisa City, Turkey, Indoor Built Environ. 15 (2006) 495-498. doi:10.1177/1420326X06069059.

[60] U. Cevik, N. Damla, R. Van Grieken, M.V. Akpınar, Chemical composition of building materials used in Turkey, Constr. Build. Mater. 25 (2011) 1546-1552. doi:10.1016/j.conbuildmat.2010.08.011.

[61] X. Msila, F. Labuschagne, W. Barnard, D.G. Billing, Radioactive nuclides in phosphogypsum from the lowveld region of South Africa, S. Afr. J. Sci. 112 (2016) 2015-102. doi:10.17159/sajs.2016/20150102.

[62] V.K. Parami, S.K. Sahoo, H. Yonehara, S. Takeda, L.L. Quirit, Accurate determination of naturally occurring radionuclides in Philippine coal-fired thermal power plants using inductively coupled plasma mass spectrometry and $\gamma$-spectroscopy, Microchem. J. 95 (2010) 181-185. doi:10.1016/j.microc.2009.11.008.

[63] P. Hayumbu, M.B. Zaman, N.C.H. Lubaba, S.S. Munsanje, D. Muleya, Natural radioactivity in Zambian building materials collected from Lusaka, J. Radioanal. Nucl. Chem. Lett. 199 (1995) 229-238. doi:10.1007/BF02162371.

[64] J.P. Bolívar, J.E. Martín, R. García-Tenorio, J.P. Pérez-Moreno, J.L. Mas, Behaviour and fluxes of natural radionuclides in the production process of a phosphoric acid plant, Appl. Radiat. Isot. 67 (2009) 345-356. doi:10.1016/j.apradiso.2008.10.012.

[65] C. Dueñas, E. Liger, S. Cañete, M. Pérez, J.P. Bolívar, Exhalation of 222Rn from phosphogypsum piles located at the Southwest of Spain, J. Environ. Radioact. 95 (2007) 63-74. doi:10.1016/j.jenvrad.2007.01.012.

[66] L. Al Attar, M. Al-Oudat, S. Kanakri, Y. Budeir, H. Khalily, A. Al Hamwi, Radiological impacts of phosphogypsum, J. Environ. Manage. 92 (2011) 2151-2158. doi:10.1016/j.jenvman.2011.03.041.

[67] F. Michael, Y. Parpottas, H. Tsertos, Gamma radiation measurements and dose rates in commonly used building materials in Cyprus, Radiat. Prot. Dosimetry. 142 (2010) 282-291. doi:10.1093/rpd/ncq193.

[68] M.M. Jankovic, D.J. Todorovic, J.D. Nikolic, Analysis of natural radionuclides in coal, slag and ash in coal-fired power plants in Serbia, J. Min. Metall. Sect. B Metall. 47 (2011) 149-155. doi:10.2298/JMMB110208008J.

[69] M.M. Makweba, E. Holm, The natural radioactivity of the rock phosphates, phosphatic products and their environmental implications, Sci. Total Environ. 133 (1993) 99-110. doi:10.1016/0048-9697(93)90115-M.

[70] A. Baeza, J.A. Corbacho, J. Guillén, A. Salas, J.C. Mora, B. Robles, D. Cancio, Enhancement of natural radionuclides in the surroundings of the four largest coal-fired power plants in Spain, J. Environ. Monit. 14 (2012) 1064. doi:10.1039/c2em10991c.

[71] E.M. El Afifi, M.A. Hilal, S.M. Khalifa, H.F. Aly, Evaluation of U, Th, K and emanated radon in some NORM and TENORM samples, Radiat. Meas. 41 (2006) 627633. doi:10.1016/j.radmeas.2005.09.014.

[72] M.S. Al-Masri, K. Haddad, NORM emissions from heavy oil and natural gas fired power plants in Syria, J. Environ. Radioact. 104 (2012) 71-74. doi:10.1016/j.jenvrad.2011.09.008.

[73] M. Ngachin, M. Garavaglia, C. Giovani, M.G. Kwato Njock, A. Nourreddine, Assessment of natural radioactivity and associated radiation hazards in some Cameroonian building materials, Radiat. Meas. 42 (2007) 61-67. doi:10.1016/j.radmeas.2006.07.007.

[74] G.A. Ayçik, A. Ercan, Radioactivity measurements of coals and ashes from coalfired power plants in the southwestern part of Turkey, J. Environ. Radioact. 35 (1997) 2335. doi:10.1016/S0265-931X(96)00031-8.

[75] U. Cevik, N. Damla, S. Nezir, Radiological characterization of Cayırhan coal-fired power plant in Turkey, Fuel. 86 (2007) 2509-2513. doi:10.1016/j.fuel.2007.02.013.

[76] C.D. Hull, W.C. Burnett, Radiochemistry of Florida phosphogypsum, J. Environ. 
Radioact. 32 (1996) 213-238. doi:10.1016/0265-931X(95)00061-E.

[77] A.R. Roper, M.G. Stabin, R.C. Delapp, D.S. Kosson, Analysis of Naturally-occurring Radionuclides in Coal Combustion Fly Ash, Gypsum, and Scrubber Residue Samples, Health Phys. 104 (2013) 264-269. doi:10.1097/HP.0b013e318279f3bf.

[78] B.H. O'connor, A.M. Donoghue, T.J.H. Manning, B.J. Chesson, Radiological assessment for bauxite mining and alumina refining, Ann. Occup. Hyg. 57 (2013) 6376. doi:10.1093/annhyg/mes052.

[79] Simin Mehdizadeh, Reza Faghihi, Sedigheh Sina, Natural radioactivity in building materials in Iran, NUKLEONIKA. 56 (2011) 363-368.

[80] X. Lu, G. Yang, C. Ren, Natural radioactivity and radiological hazards of building materials in Xianyang, China, Radiat. Phys. Chem. 81 (2012) 780-784. doi:10.1016/j.radphyschem.2012.02.043.

[81] M. Lust, E. Realo, Assessment of natural radiation exposure from building materials in Estonia, Proc. Est. Acad. Sci. 61 (2012) 107. doi:10.3176/proc.2012.2.03.

[82] G. Sciocchetti, G.F. Clemente, G. Ingrao, F. Scacco, Results of a Survey on Radioactivity of Building Materials in Italy, Health Phys. 45 (1983) 385-388. doi:10.1097/00004032-198308000-00011.

[83] J. Somlai, V. Jobbágy, J. Kovács, S. Tarján, T. Kovács, Radiological aspects of the usability of red mud as building material additive, J. Hazard. Mater. 150 (2008) 541545. doi:10.1016/j.jhazmat.2007.05.004.

[84] M.A. Kobeissi, O. El Samad, K. Zahraman, S. Milky, F. Bahsoun, K.M. Abumurad, Natural radioactivity measurements in building materials in Southern Lebanon, J. Environ. Radioact. 99 (2008) 1279-1288. doi:10.1016/j.jenvrad.2008.03.007.

[85] L. Xinwei, Radioactive analysis of cement and its products collected from Shaanxi, China., Health Phys. 88 (2005) 84-86. doi:10.1097/01.HP.0000142498.08451.c8.

[86] L. Xinwei, W. Fengling, J. Xiaodan, W. Lingqing, Radioactive analysis and radiological hazards of lime and cement fabricated in China, IEEE Trans. Nucl. Sci. 54 (2007) 327-332. doi:10.1109/TNS.2007.892335.

[87] X. Lu, N. Li, G. Yang, C. Zhao, Assessment of Natural Radioactivity and Radiological Hazards in Building Materials Used in Yan'an, China, Health Phys. 104 (2013) 325331. doi:10.1097/HP.0b013e31827a7ea2.

[88] D. Georgescu, F. Aurelian, M. Popescu, C. Radulescu, IAEA-TECDOC-1472 Sources of tenorm - inventory of phosphate fertilizer and aluminium industry, in: 2005: pp. 87-96.

[89] N. Damla, U. Cevik, A.I. Kobya, A. Celik, N. Celik, Assessment of natural radiation exposure levels and mass attenuation coefficients of lime and gypsum samples used in Turkey, Environ. Monit. Assess. 170 (2010) 457-466. doi:10.1007/s10661-009-12465.

[90] Z. Szabó, P. Völgyesi, H.É. Nagy, C. Szabó, Z. Kis, O. Csorba, Radioactivity of natural and artificial building materials - a comparative study, J. Environ. Radioact. 118 (2013) 64-74. doi:10.1016/j.jenvrad.2012.11.008.

[91] M.E. Medhat, Assessment of radiation hazards due to natural radioactivity in some building materials used in Egyptian dwellings, Radiat. Prot. Dosimetry. 133 (2009) 177-185. doi:10.1093/rpd/ncp032.

[92] N.K. Ahmed, Measurement of natural radioactivity in building materials in Qena city, Upper Egypt, J. Environ. Radioact. 83 (2005) 91-99. doi:10.1016/j.jenvrad.2005.03.002.

[93] S.M. El-Bahi, Assessment of radioactivity and radon exhalation rate in Egyptian cement., Health Phys. 86 (2004) 517-522. doi:10.1097/00004032-200405000-00008.

[94] L.A. Wendling, M.T. Binet, Z. Yuan, F. Gissi, D.J. Koppel, M.S. Adams, Geochemical and ecotoxicological assessment of iron- and steel-making slags for potential use in environmental applications, Environ. Toxicol. Chem. 32 (2013) n/a-n/a. doi:10.1002/etc. 2342 .

[95] T. Sofilić, D. Barišić, U. Sofilić, Natural radioactivity in steel slag aggregate, Arch. Metall. Mater. 56 (2011) 627-634. doi:10.2478/v10172-011-0068-y.

[96] D. Xirouchakis, V. Manolakou, Properties of an EAf slag produced in Greece : a 
construction material for sustainable growth, 5th Int. Conf. Bitum. Mix. Pavements. (2011) 2-3.

[97] M. Zalewski, M. Tomczak, J. Kapała, Radioactivity of Building Materials Available in Northeastern Poland, Polish J. Environ. Stud. 10 (2001) 183-188.

[98] G. Tanase, M. Tanase, Natural radioactivity in iron and steel materials by low-level gamma spectrometry, Rom. J. Phys. 48 (2003) 363-368.

[99] A. Ene, A. Pantelică, Characterization of metallurgical slags using low-level gammaray spectrometry and neutron activation analysis, Rom. Reports Phys. 56 (2011) 10111018.

[100] S. Stoulos, M. Manolopoulou, C. Papastefanou, Assessment of natural radiation exposure and radon exhalation from building materials in Greece, J. Environ. Radioact. 69 (2003) 225-240. doi:10.1016/S0265-931X(03)00081-X.

[101] A.A. Pakou, P.A. Assimakopoulos, M. Prapidis, Natural radioactivity and radon emanation factors in building material used in Epirus (North-Western Greece), Sci. Total Environ. 144 (1994) 255-260. doi:10.1016/0048-9697(94)90444-8.

[102] J. Van Der Steen, Regulatory approaches for NORM residues in the Netherlands, Regul. Manag. Approaches Control Environ. Residues Contain. Nat. Occur. Radioact. Mater. I (2004) 61-73.

[103] G.M. Crockett, K.R. Smith, W.B. Oatway, S.F. Mobbs, NRPB-W48 Radiological impact on the UK population of industries which use or produce materials containing enhanced levels of naturally occurring radionuclides Part II: The steel production industry, 2003. http://www.peacelink.it/ecologia/docs/2825.pdf.

[104] A. Kumar, M. Kumar, B. Singh, S. Singh, Natural activities of 238U, 232Th and 40K in some Indian building materials, Radiat. Meas. 36 (2003) 465-469. doi:10.1016/S1350-4487(03)00173-2.

[105] G.M. Brahmanandhan, J. Malathi, D. Khanna, S. Selvasekarapandian, N. Nidhya, R. Usharani, M.T. Jose, V. Meenakshisundaram, Natural radioactivity and indoor radiation measurements in buildings and building materials in Gobichettipalayam town, J. Radioanal. Nucl. Chem. 274 (2007) 373-377. doi:10.1007/s10967-007-1125-x.

[106] M.H.T. Taddei, The natural radioactivity of Brazilian phosphogypsum, in: J. Radioanal. Nucl. Chem., 2001: pp. 251-255. doi:10.1023/A:1013215215484.

[107] F.T. da Conceição, D.M. Bonotto, Radionuclides, heavy metals and fluorine incidence at Tapira phosphate rocks, Brazil, and their industrial (by) products, Environ. Pollut. 139 (2006) 232-243. doi:10.1016/j.envpol.2005.05.014.

[108] C.H. Saueia, B.P. Mazzilli, D.I.T. Fávaro, Natural radioactivity in phosphate rock, phosphogypsum and phosphate fertilizers in Brazil, J. Radioanal. Nucl. Chem. 264 (2005) 445-448. doi:10.1007/s10967-005-0735-4.

[109] A.J.G. Santos, B.P. Mazzilli, D.I.T. Fávaro, P.S.C. Silva, Partitioning of radionuclides and trace elements in phosphogypsum and its source materials based on sequential extraction methods, J. Environ. Radioact. 87 (2006) 52-61. doi:10.1016/j.jenvrad.2005.10.008.

[110] B. Mazzilli, C. Saueia, Radiological implications of using phosphogypsum as a building material in Brazil, Radiat. Prot. Dosimetry. 86 (1999) 63-67.

[111] C.H.R. Saueia, B.P. Mazzilli, Distribution of natural radionuclides in the production and use of phosphate fertilizers in Brazil, J. Environ. Radioact. 89 (2006) 229-239. doi:10.1016/j.jenvrad.2006.05.009.

[112] E.M. Lee, G. Menezes, E.C. Finch, Natural Radioactivity in Building Materials in the Republic of Ireland, Health Phys. 86 (2004) 378-383. doi:10.1097/00004032200404000-00007.

[113] M. Omar, NORM waste management in Malaysia, Int. Conf. Saf. Radioact. Waste Manag. (2000) 89-92.

[114] K.M. Kontol, S.H.S.S. Ahmad, M. Omar, Radiological impact assessment for landfill disposal of NORM wastes in Malaysia, in: Nat. Occur. Radioact. Mater. ( NORM V), 2007: pp. 355-359.

[115] S. Righi, S. Verità, A. Albertazzi, P.L. Rossi, L. Bruzzi, Natural radioactivity in refractory manufacturing plants and exposure of workers to ionising radiation, $\mathrm{J}$. 
Environ. Radioact. 100 (2009) 540-546. doi:10.1016/j.jenvrad.2009.03.008.

[116] R. Shweikani, M. Kousa, F. Mizban, The use of phosphogypsum in Syrian cement industry: Radiation dose to public, Ann. Nucl. Energy. 54 (2013) 197-201. doi:10.1016/j.anucene.2012.11.010.

[117] European Commission, Materials containing natural radionuclides in enhanced concentrations - Report EUR 17625, Brussels, Belgium : European Commission, 1997.

[118] E.M. Hussein, Radioactivity of Phosphate Ore, Superphosphate, and Phosphogypsum in Abu-zaabal Phosphate Plant, Egypt, Health Phys. 67 (1994) 280-282. doi:10.1097/00004032-199409000-00010.

[119] European Commission, Radiological protection principles concerning the natural radioactivity of building materials - Radiation Protection 112, Eur. Comm. (1999) 116.

[120] Cost network NORM4Building, NORM4Building database, (2017). www.norm4building.org.

[121] K.-H. Puch, R. Bialucha, G. Keller, Naturally occurring radioactivity in industrial byproducts from coal-fired power plants, from municipal waste incineration and from the iron- and steel-industry, in: 2005: pp. 996-1008. doi:10.1016/S1569-4860(04)07123-2.

[122] T. Croymans, I. Vandael Schreurs, M. Hult, G. Marissens, G. Lutter, H. Stroh, S. Schreurs, W. Schroeyers, Variation of natural radionuclides in non-ferrous fayalite slags during a one-month production period, J. Environ. Radioact. 172 (2017) 63-73. doi:10.1016/j.jenvrad.2017.03.004.

[123] J.H. Selby, The industrial uses of zircon and zirconia and the radiological consequences of these uses., in: Nat. Occur. Radioact. Mater. (NORM V). Proc. an Int. Symp., Seville, 2007: p. 95-116.

[124] E.V. Churchill, S.N. Amirkhanian, Coal Ash Utilization in Asphalt Concrete Mixtures, J. Mater. Civ. Eng. 11 (1999) 295-301. doi:10.1061/(ASCE)08991561(1999)11:4(295).

[125] European Fly Ash Association, Ecoba website, (n.d.). www.ecoba.com (accessed July 15, 2017).

[126] K. Kovler, Does the utilization of coal fly ash in concrete construction present a radiation hazard?, Constr. Build. Mater. 29 (2012) 158-166. doi:10.1016/j.conbuildmat.2011.10.023.

[127] C. Argiz, E. Menendez, A. Moragues, M.A. Sanjuan, Fly ash characteristics of Spanish coal-fired power plants, Afinidad. LXXII (2015) 269-277. http://www.ieaetsap.org/web/E-TechDS/PDF/E01-coal-fired-power-GS-AD-gct.pdf.

[128] I. Ignjatović, Z. Sas, J. Dragaš, J. Somlai, T. Kovács, Radiological and material characterization of high volume fly ash concrete, J. Environ. Radioact. 168 (2017) 3845. doi:10.1016/j.jenvrad.2016.06.021.

[129] C. Shi, C. Meyer, A. Behnood, Utilization of copper slag in cement and concrete, Resour. Conserv. Recycl. 52 (2008) 1115-1120. doi:10.1016/j.resconrec.2008.06.008.

[130] T. Croymans, W. Schroeyers, P. Krivenko, O. Kovalchuk, A. Pasko, M. Hult, G. Marissens, G. Lutter, S. Schreurs, Radiological characterization and evaluation of high volume bauxite residue alkali activated concretes, J. Environ. Radioact. 168 (2017) 2129. doi:10.1016/j.jenvrad.2016.08.013. 